\author{
Universidade de São Paulo \\ Faculdade de Filosofia, Letras e Ciências Humanas \\ Departamento de Letras Modernas \\ Programa de Pós-graduação em Estudos Lingüísticos e Literários \\ em Inglês
}

\title{
Figurações da indefinição: a epistemologia travada de Matrix
}

Marcelo Cizaurre Guirau

Dissertação apresentada ao

Programa de Pós-graduação em

Estudos Lingüísticos e Literários em Inglês do Departamento de Letras Modernas da Universidade de São Paulo, como parte dos pré-requisitos para a obtenção do título de mestre em Letras.

Orientador: Prof. Dr. Marcos César de Paula Soares

São Paulo

2007 


\author{
Universidade de São Paulo \\ Faculdade de Filosofia, Letras e Ciências Humanas \\ Departamento de Letras Modernas \\ Programa de Pós-graduação em Estudos Lingüísticos e Literários \\ em Inglês
}

Figurações da indefinição: a epistemologia travada de Matrix

Marcelo Cizaurre Guirau

São Paulo

2007 
Serviço de Biblioteca e Documentação da Faculdade de Filosofia, Letras e Ciências Humanas da Universidade de São Paulo

\section{Guirau, Marcelo Cizaurre}

Figurações da indefinição : a epistemologia travada de Matrix / Marcelo Cizaurre Guirau ; orientador Marcos César de Paula Soares. -- São Paulo, 2007.

$122 \mathrm{p}$.

Dissertação (Mestrado - Programa de Pós-Graduação em Estudos Lingüísticos e Literários em Inglês. Área de concentração: Literatura e Cinema) - Departamento de Letras Modernas da Faculdade de Filosofia, Letras e Ciências Humanas da Universidade de São Paulo.

1. Filosofia do Cinema. 2. Matrix (Crítica; Análise). 3. Epistemologia. 4. Semiologia do Cinema. 5. Literatura e Cinema - Estados Unidos - Século 20. I. Título. 
Aos meus pais.

À Yifang, por tudo. 


\section{Agradecimentos}

Ao meu orientador pela disponibilidade em ajudar, seriedade na orientação, olhar crítico e confiança no meu trabalho.

Às professoras Maria Elisa Cevasco e Maria Sílvia Betti pela leitura crítica e pelos comentários que enriqueceram esse trabalho.

À Coordenação de Aperfeiçoamento de Pessoal de Nível Superior (CAPES) pela concessão da bolsa de mestrado e pelo apoio financeiro para a realização dessa pesquisa.

Ao amigo Alexandre Agnolon pela revisão cuidadosa e pelas valiosas sugestões.

Aos amigos Alan Nicholiche, Andréa Gomes de Alencar, Cíntia Kaori, Eliete Farneda, Ricardo Quindós, Kelly Marques, Solange Grossi e Zilah Aparecida Peigo de Moura e Silva, pelo apoio. 


\section{Resumo}

Neste trabalho, estudaremos os filmes da trilogia Matrix do ponto de vista da figuração.

A análise do tecido narrativo dos filmes objeto desse estudo revela uma série de falhas e inconsistências. Essas falhas expõem alguns dilemas da experiência sob o domínio do capitalismo tardio. As zonas de ambigüidade e indefinição que identificamos em Matrix nos orientaram a pensar essa obra cinematográfica como um esforço cognitivo mal resolvido. Essa é a epistemologia travada de Matrix, que será estudada não como uma simples falha de diagnóstico resultante da falta de lucidez cognitiva dos criadores da série, mas sim como um exemplar significativo da exposição de limites da figuração histórica.

Palavras-chave: literatura e cinema, sociologia da literatura, ficção científica, figuração, reificação e utopia. 


\section{Abstract:}

In this work, we are going to study the Matrix trilogy from the perspective of figuration.

The analysis of the narrative fabric of these movies reveals many failures and inconsistencies. Such failures expose some dilemmas of the experience under the domain of late capitalism. The ambiguity and indetermination zones which we identified in Matrix have led us to think these movies to be an unsolved cognitive effort. This is the jammed epistemology of Matrix, which is going to be analyzed not as a simple diagnosis failure due to the movies' creator's lack of cognitive lucidity, but as a significant example of the exposition of the limits of historical figuration.

Key-words: literature and cinema, sociology of literature, science-fiction, figuration, reification and utopia. 
Aporias críticas

Matrix como "ato socialmente simbólico".... .33

Hermenêutica da Máquina: da retórica ao conceito 38

A Máquina como tópos do "anticapitalismo romântico" 39

O Admirável Mundo Novo de Matrix 57

A "Alegoria da desconexão" e o paradoxo da autonomia sem escolha 63

"Ignorance is bliss": Cypher e a desilusão 78

Ambigüidades e zonas de indefinição. 81

A máquina como totalidade 93

Conclusão. 112

Referências bibliográficas:. 


\section{Introdução}

Nenhum outro filme de ação mobilizou tanta energia intelectual quanto Matrix ${ }^{1}$. Em geral, filmes de ação se prestam mais ao arrebatamento sensorial e a distração do que à contemplação meditativa ${ }^{2}$. Matrix difere dos outros filmes de ação por sua declarada pretensão intelectual e por tentar acomodar cogitações filosóficas numa forma, o cinema de ação, cuja acentuada vocação para o entorpecimento dos sentidos é patente.

Podemos dizer que "Matrix" inaugura a inusitada categoria dos filmes de ação com referências bibliográficas. No próprio site da trilogia (www.thematrix.com) podemos encontrar uma série de artigos, escritos por acadêmicos, que identificam e discutem as várias referências filosóficas do filme.

\footnotetext{
${ }^{1}$ Neste trabalho, usaremos Matrix para nos referirmos à trilogia ou ao universo ficcional nela desenhado; usaremos Matriz para falarmos especificamente da figura da matriz nos filmes; e usaremos "Matrix" para o primeiro filme da série.

${ }^{2}$ Walter Benjamin já observava essa tendência à distração nos primeiros tempos do cinema: " $A$ recepção através da distração, que se observa crescentemente em todos os domínios da arte e constitui o sintoma de transformações profundas nas estruturas perceptivas, tem no cinema o seu cenário privilegiado". BENJAMIN, Walter. Magia e técnica, arte e política. São Paulo: Brasiliense, 1985. p.192). A rapidez com que as imagens desfilam na tela do cinema é identificada como elemento propiciador de choque e distração: "Compare-se a tela em que se projeta o filme com a tela em que se encontra o quadro. Na primeira, a imagem se move, mas na segunda, não. Esta convida o espectador à contemplação; diante dela, ele pode abandonarse às suas associações. Diante do filme, isso não é mais possível. Mal o espectador percebe uma imagem, ela não é mais a mesma. Ela não pode ser fixada, nem como um quadro nem como algo de real. A associação de idéias do espectador é interrompida imediatamente, com a mudança da imagem. Nisso se baseia o choque provocado pelo cinema, que, como qualquer outro choque, precisa ser interceptado por uma atenção aguda" (Ibid., p.192). Nos atuais filmes de ação, a tendência identificada por Benjamin se confirma e se renova.
} 
O primeiro filme da série traz várias citações de filósofos e de problemas filosóficos, como o da natureza do real e os conceitos de simulacro e simulação ${ }^{3}$.

As pretensões filosóficas de Matrix são confirmadas pelos próprios criadores da série:

Nossa principal intenção com Matrix foi fazer um filme de ação intelectualizado. Gostamos de filmes de ação, armas de fogo e kung-fu, mas estamos cansados dos filmes de ação padronizados que não têm conteúdo intelectual. Estávamos dispostos a colocar no filme o máximo de idéias possívelł.

A questão da relevância filosófica de Matrix ocupou inúmeras páginas de jornais, revistas e livros. Muitos desses escritos se dedicaram a um julgamento do filme como mero entretenimento enrustido de elevado saber ou como uma reflexão filosófica genuína digna de séria reflexão.

\footnotetext{
${ }^{3}$ Há, nesse filme, uma citação direta a Jean Baudrillard. Isso acontece na cena em que Neo, o herói da trilogia, retira drogas de simulação de dentro do livro Simulacro e Simulação. A citação a Baudrillard foi atenuada na versão final do filme, uma vez que, no roteiro original, havia uma cena em que Morfeu, em conversa com Neo, citaria nominalmente o autor francês: "Você tem vivido dentro da concepção de Baudrillard, dentro do mapa, não do território" (YEFFETH, Glenn (org.) A pílula vermelha: questões de ciência, filosofia e religião em Matrix. São Paulo: Publifolha, 2003. p. 97). O próprio Baudrillard foi procurado para participar da concepção do filme, como ele mesmo revela em entrevista para a revista Le Nouvel Observateur. "Le staff des Wachowski m'avait d'ailleurs contacté après le premier épisode pour m'impliquer dans les suivants, mais ce n'était vraiment pas concevable" (Baudrillard decode Matrix. Le Nouvel Observateur, 19 jun. 2003)

${ }^{4}$ Entrevista concedida por Larry Wachowski. YEFFETH, op. cit., p. 97.
} 
Mais interessante do que decidir sobre o mérito filosófico do filme é investigar a inquietação teórica gerada por Matrix. A esse respeito, o filósofo francês Elie During destaca:

Nos campi universitários dos EUA e da Inglaterra, Matrix provocou uma atividade teórica e interpretativa bastante intensa. Não se trata de saber se é a filosofia com "f" maiúsculo, mas de constatar a energia e o desejo teórico que Matrix desencadeou ${ }^{5}$.

Esse "desejo teórico" foi convertido em toneladas de papel impresso em mais de 19 livros. Alguns deles serão comentados na primeira parte do capítulo 1.

A leitura de parte desse material e de muitos outros textos escritos sobre os filmes da trilogia Matrix deixou evidente o fato de que a figura da Matriz possui uma espécie de abertura simbólica, que foi explorada em variados contextos. Falaremos sobre o caráter polissêmico dessa figura ainda no primeiro capítulo.

Nesse mesmo capítulo, trataremos das dificuldades de análise que o nosso objeto de estudo impõe e finalizaremos com uma breve exposição da estratégia de análise que será desenvolvida no segundo capítulo.

\footnotetext{
${ }^{5}$ DURING, Elie In AZOURY, Philippe; DIDIER, Peron. Máquina de Mitos: autores franceses discutem tecnofilosofia de "Matrix" em livro. Folha de São Paulo, São Paulo, 9 nov. 2003. Ilustrada, Caderno E, p. 7. [Texto originalmente publicado no Libération]
} 
Descartando-se a hipótese de que as cogitações filosóficas desenhadas em Matrix devam ser atribuídas exclusivamente à vaidade intelectual dos criadores da série, temos que esse complexo emaranhado de inquietações, problemas, citações, hipóteses etc... encera um instantâneo da desorientação cognitiva característica do nosso tempo. Para Erick Felinto:

Matrix pode, de fato, ser lido como uma síntese conflitiva de certos elementos estruturais da cultura "pós-moderna" (se é que realmente existe tal coisa): a ascensão de formas de religiosidade não tradicionais, o culto da tecnologia, o domínio de filosofias e visões de mundo relativistas. A encenação combinada desses elementos, para funcionar adequadamente, necessita de determinado grau de inconsciência ${ }^{6}$.

O "determinado grau de inconsciência" de que Matrix necessita para abrigar tamanho volume de informação é sintomático da desorientação cognitiva de que falamos acima. A filosofia de Matrix não deve ser buscada nas muitas citações filosóficas que o filme traz, mas sim no impulso totalizador (naquele desejo latente de explicar a totalidade da experiência vivida) ao qual as citações estão subordinadas.

\footnotetext{
${ }^{6}$ FELINTO, Erick. A religião das máquina: ensaios sobre o imaginário da cibercultura. Porto Alegre: Sulina, 2005. p. 13.
} 
O complexo tecido de relações que Matrix tenta costurar com as inúmeras referências que o filme traz pode ser lido como uma tentativa inconsciente de se criar um "efeito de fechamento". Fredric Jameson, em sua análise de filmes de conspiração", chegou ao conceito de "closure-effect", o qual nos ajuda a entender o impulso totalizador que observamos em Matrix. Sobre essa tentativa de dominar simbolicamente a totalidade da experiência social, Jameson explica:

Closure is, to be sure, one of the fundamental formal question one wishes to ask of conspiratorial representations of this type, [Videodrome] where its effect is clearly fundamentally related to the problem of totality itself. For the sense of closure here is the sign that somehow all the bases have been touched, and that the galactic dimensions and co-ordinates of the now global social totality have at least been sketched in. It should be obvious that, just as such totalities can never be perceived with the naked eye (where they would remain, in any case, purely contemplative and epistemological images), so also closure in the postmodern, after the end of the (modernist) organic work, has itself become a questionable value, if not a meaningless concept. It will be desirable therefore to speak of a closure-effect, just as we speak

\footnotetext{
${ }^{7} C f$. JAMESON, Fredric. The geopolitical aesthetic: cinema and space in the world system. Bloomington; London: Indiana University Press: BFI Pub., 1995.
} 
of mapping out or triangulating, rather than perceiving or representing, a totality ${ }^{8}$.

No segundo capítulo dessa dissertação, estudaremos o "efeito de fechamento" esboçado em Matrix.

Seguiremos um itinerário de análise que começa no estudo do tópos da máquina como "alegoria do socialmente negativo"; passa por uma comparação de Matrix com o romance Admirável Mundo Novo, de Aldous Huxley; estuda as ambigüidades e indefinições do tecido narrativo dos filmes e a "epistemologia travada" de Matrix e termina com um estudo do "efeito de fechamento" que aparece esboçado nos filmes da trilogia aqui estudada.

Tentaremos, com esse trabalho, nos defrontarmos com alguns desafios analíticos que o nosso objeto de estudo suscita. Conduziremos esse estudo como um exercício epistemológico.

${ }^{8}$ JAMESON, Fredric. The geopolitical aesthetic: cinema and space in the world system. Bloomington; London: Indiana University Press: BFI Pub., 1995. p. 31. 


\section{A recepção crítica de Matrix}

\section{Apropriações alegóricas da figura da Matriz}

Em toda a vasta bibliografia sobre Matrix, a melhor resposta que encontrei para a pergunta acima é, paradoxalmente, a mais aberta à polissemia. Slavoj Zizek define a Matrix como uma espécie de versão cinematográfica do teste de Rorschach (aquele teste em que é mostrada uma folha com borrões e o paciente é perguntado sobre o que vê):

Matrix não é um daqueles filmes que funcionam como um tipo de teste de Rorschach, colocando em movimento o processo universalizado de reconhecimento, como a pintura proverbial de Deus, que parece sempre estar olhando diretamente para você, de qualquer ângulo que você veja - com o qual praticamente toda espécie de orientação parece se identificar? Meus amigos lacanianos me dizem que os autores devem ter lido Lacan; os partidários da Escola de Frankfurt vêem em Matrix a personificação extrapolada da Kulturindustrie, a substância social reificada e alienada (do capital) diretamente dominando tudo, colonizando nossa própria vida interior, usando-nos como fonte de energia; os adeptos da Nova Era vêem no filme uma fonte de 
especulações sobre como nosso mundo é apenas uma miragem gerada por uma mente global personificada na rede mundial, ou World Wide Web ${ }^{9}$.

Essa polissemia da figura da Matriz foi amplamente explorada pela indústria editorial. Em pesquisas na Internet, encontramos dezenove livros dedicados à trilogia Matrix ou que se apropriam da figura da Matriz para fins retóricos ou simbólicos diversos. Exemplo desse tipo de apropriação é o livro "The Gospel Reloaded: Exploring Spirituality and Faith in The Matrix"1." A sinopse que está no site da livraria Amazon exclarece as intenções dos autores dessa obra:

like any pop culture phenomenon worth its salt, the film managed to be all things to all people, claimed by Christians as an allegory of resurrection and by Buddhists as a metaphor of awakening. Seay and Garrett are primarily concerned with the movie's Christian themes-Neo as the Christ; Morpheus as the John the Baptist figure who prepares the way; and Trinity as the female face of God ${ }^{11}$.

\footnotetext{
${ }^{9}$ ZIZEK, Slavoj. Matrix: ou os Dois Lados da Perversão In IRWIN, William (Org). Matrix: Bem-Vindo ao Deserto do Real, São Paulo: Madras, 2003. p. 259.

${ }^{10}$ SEAY, Christopher; GARRETT, Greg. The Gospel Reloaded: Exploring Spirituality and Faith in The Matrix. USA: Pinon Press, 2003.

${ }^{11}$ (http://www.amazon.com/Gospel-Reloaded-Exploring-Spirituality-Matrix/dp/1576834786)
} 
Uma rápida leitura da contracapa e de algumas páginas disponíveis para a consulta do comprador confirmam a intenção dos autores de utilizar os filmes da trilogia Matrix com fins doutrinários.

A "pop philosophy" foi outro mercado promissor para os filmes da trilogia Matrix. Esse grupo de publicações pode ser dividido em duas tendências: livros que levam a sério as premissas do mundo de Matrix e tentam provar que estamos todos presos na nossa Matriz (as Matrizes podem variar de autor para autor) e livros que usam os filmes como ilustração de teses filosóficas diversas. O livro "Exegesis of the Matrix", por exemplo, participa dessas duas tendências, como podemos perceber na descrição do livro:

It examines carefully the question of whether the world of the Matrix is possible (...) After establishing that the Matrix films make technological and philosophical sense, the author lays out the main philosophical sources that the Wachowskis have drawn upon. Here we find clear introductions to the philosophies of Plato, Descartes, Berkeley, Schopenhauer, and Kant. Lloyd then goes on to analyse the religious themes of the films, and the complex web of allusions to all the major religions. The book closes with a critique of the political messages of the film: jazz politics, and the dangers of slipping into terrorism and fascism ${ }^{13}$.

\footnotetext{
${ }^{12}$ LLOYD, Peter B. Exegesis of the Matrix. New York: Whole-Being Books, 2003.

${ }^{13}$ (http://www.amazon.co.uk/Exegesis-Matrix-Peter-B-Lloyd/dp/1902987098)
} 
$\mathrm{Na}$ sinopse desse mesmo livro, temos um resumo da estratégia de exploração que algumas publicações utilizaram para ingressar nas benesses comerciais ${ }^{14}$ da "marca" Matrix:

Although there is no heavyweight message or unifying meaning in the films, there are a lot of interesting threads of thought. Teasing out these threads and seeing where they lead can take you down some deep rabbit-holes. This book is a guide to some of the threads that have been disentangled from this cinematic tapestry, and to the rabbit holes they lead down ${ }^{15}$.

Grande parte dos livros escritos sobre Matrix versa sobre questões filosóficas contidas no enredo da série. Sobre a abrangência filosófica de Matrix, Stephen Faller comenta: "The simple fact is that nearly every branch of philosophy has some connection with the Matrix movies ${ }^{16 " .}$

Essa forte vocação filosófica de Matrix abre caminho para especulações das mais variadas. Quem não se sentir satisfeito apenas com as elaboradíssimas cenas de ação do filme, pode encontrar em Matrix a

\footnotetext{
${ }^{14}$ Façamos a ressalva de que nem todos os livros inspirados nos filmes da trilogia Matrix são obra do mero interesse comercial de seus autores, editores e demais possíveis beneficiários. Dentro da bibliografia sobre Matrix, há publicações interessadas em estudar o fenômeno cinematográfico que esse filme representou e em dedicar atenção crítica ao conteúdo filosófico da trilogia. Nesse trabalho, não nos dedicaremos, por questões de espaço e de prioridade epistemológica, a uma descrição detalhada da bibliografia sobre Matrix. Deixaremos para o leitor a tarefa de julgar o interesse crítico de cada um desses escritos.

${ }^{15}$ Ibidem.

${ }^{16}$ FALLER, Stephen. Beyond the Matrix: Revolutions and Revelations. USA: Chalice Press, 2004. p. 19.
} 
mensagem certa para suas inquietações existenciais. Pelo menos é isso o que prometem alguns dos livros dedicados à trilogia, como é o caso de "Like a Splinter in Your Mind: The Philosophy Behind the 'Matrix' Trilogy ${ }^{17 " . ~ A ~ d e s c r i c ̧ a ̃ o ~}$ do livro é esclarecedora:

The Matrix films are not just about Kung Fu and special effects. Rather, they are about knowledge, reality, consciousness, freedom, fate, foreknowledge, good, evil, faith, enlightenment, and the very meaning of existence. In short, they are about philosophy - with some impressive special effects on the side ${ }^{18}$.

A polissemia de Matrix não passou despercebida da lucrativa indústria da auto-ajuda. A mensagem de libertação e de auto-descoberta que pode ser retirada do enredo do filme foi convertida em exemplo e inspiração pelos gurus do bem-viver. O livro "Matrix Reflections: Choosing Between Reality And Illusion" segue essa receita, como podemos observar na sinopse que encontramos na contracapa:

The Matrix Reflections acts as a tool, a mirror, a key that unlocks some answers to the very questions that we encounter throughout our lives. It invites us to take a journey, like Neo, the hero of the films, to discover the truth about our world and it's

\footnotetext{
${ }^{17}$ LAWRANCE, Matt. Like a Splinter in Your Mind: The Philosophy Behind the 'Matrix' Trilogy. Oxford: Blackwell, 2004.

${ }^{18}$ (http://www.amazon.com/Like-Splinter-Your-Mind-Philosophy/dp/1405125241)
} 
illusions. Come and explore the Matrix films deeper and discover the answers to the Big Questions of life ${ }^{19}$.

Ainda na seção de auto-ajuda encontramos o livro "The One (Matrix Book) (Matrix Reprogrammed)". Esse livro promete "incrementar" (supercharge, no original) a vida do leitor usando o filme como um "modelo de desenvolvimento humano ${ }^{20 "}$. Na descrição do livro, temos um sumário da sabedoria que a obra pretende tirar da trilogia Matrix:

Get Unplugged. Free Your Mind. Create Your Life. A Revolutionary Self-Empowerment book based on The Matrix Movies! Ever wonder what it would be like to become the "One" (Neo). . . now here is your opportunity to go on a fantastic journey.

- Discover how to shatter personal barriers that are holding you back.

- Develop strong confidence in making the most important choices in your life simpler.

- Take control of your belief systems which could be sabotaging your life.

- Assemble a loyal, unlimited, indestructible lifeachievement team.

\footnotetext{
19 ZACAPA. Eddie. Matrix Reflections: Choosing Between Reality And Illusion. USA: Authorhouse, 2005.

${ }^{20}$ (http://www.amazon.com/One-Matrix-Book-Reprogrammed/dp/0970979614)
} 
- Prepare for the success that you deserve by re-training your mind, body and soul.

- Catch your defining moments by releasing the power within.

- Connect with the power of love.

- Find your own "Morpheus" to be a mentor in your life ${ }^{21}$.

A variada gama de interpretações que a figura da Matriz inspirou alimenta a idéia de que Matrix seria uma espécie de enigma permanente, um objeto que não admite outra coisa que não seja a polissemia e a indefinição. Para Matt Lawrence, autor de "Like a Splinter in Your Mind: The Philosophy Behind the 'Matrix' Trilogy", "it's safe to say that no one understands the films completely - there are always deeper levels to consider ${ }^{22 " .}$

Os filmes da trilogia Matrix lançaram um novo significante no mercado. A figura da Matriz, como vimos nos exemplos acima, pode ser requisita para os mais variados fins retóricos e simbólicos. Ao significar tudo, a palavra Matrix acaba não significando nada. Tentar buscar uma definição para ela seria cair na armadilha epistemológica da polissemia que o próprio termo suscita. Em vez disso, preferimos estudar a própria indefinição dessa figura como sintoma de uma época de desorientação política.

Qualquer análise que se defronte com um objeto tão polissêmico quanto a figura da Matriz corre o risco que se tornar apenas mais uma possibilidade de

\footnotetext{
${ }^{21}$ (http://www.amazon.com/One-Matrix-Book-Reprogrammed/dp/0970979614)

${ }^{22}$ Op. cit., p. 7.
} 
leitura no infinito mercado das interpretações. Para fugirmos desse risco faremos uma leitura do fenômeno Matrix como "sintoma instrutivo ${ }^{23 "}$ de alguns dos dilemas mais significativos do pensamento crítico atual. Aprofundaremos essa análise no próximo capitulo.

\section{Aporias críticas}

O moebius de indefinição que a figura da Matriz parece suscitar encontra respaldo teórico em algumas teorias da pós-modernidade como Era de uma indefinição constitutiva.

Hoje, o mercado de interpretações aparece cada vez mais saturado. A falta de certezas que marca o presente momento histórico é usada como autorização para devaneios teóricos dos mais "criativos". O vazio político que, em grande parte, explica a inquietação da teoria hoje (Matrix é parte desse fenômeno) dá origem também a uma enxurrada de lançamentos teóricos que entopem o competitivo mercado de interpretações do real (ver a primeira parte desse capítulo para ter uma amostra desse mercado).

Para Zizek, a teoria acompanha as exigências do mundo atual:

Today, in a time of continuous rapid changes, from the

${ }^{23}$ Baudrlillard decode Matrix. Le Nouvel Observateur, 19 jun. 2003. 
'digital revolution' to the retreat of old social forms, thought is more than ever exposed to the temptation of 'losing its nerve', of precociously abandoning the old conceptual coordinates. The media constantly bombard us with the need to abandon the 'old paradigms': if we are to survive, we have to change our most fundamental notions of what constitutes personal identity, society, environment, etc...24.

Como exemplo de empreendimentos teóricos que privilegiam a indeterminação como recurso epistemológico veremos o "Manifesto Ciborgue", de Donna Haraway, e alguns momentos da obra de Jean Baudrillard.

Acreditamos que essas duas leituras podem enriquecer o presente trabalho por apresentarem sintomas da mesma desorientação política de que a "epistemologia travada" de Matrix é fruto. Lembramos que Baudrillard é nominalmente citado no filme e em diversas entrevistas do elenco e dos diretores da trilogia. Quanto ao "Manifesto Ciborgue", sua aproximação de Matrix se dá pela ânsia de criar uma figura que funcione, retórica e simbolicamente, como síntese totalizadora (no caso de Matrix, a figura da Matriz; no caso do manifesto, a figura do Ciborgue).

Em seu manifesto, Donna Haraway contesta certos dualismos que persistem na tradição ocidental e seriam responsáveis pela dominação de tudo que se constitui como o outro ${ }^{25}$. Para ela,

\footnotetext{
${ }^{24}$ ZIZEK, Slavoj. On Belief. London/New York: Routledge, 2001, p. 32.

${ }^{25}$ A autora cita alguns desses dualismos: self/other, mind/body, culture/nature, male/female, civilized/primitive, reality/appearance, whole/part, agent/resource, maker/ made, active/passive, right/wrong, truth/illusion, total/partial, God/man. HARAWAY, Donna. A
} 
High-tech culture challenges these dualisms in intriguing ways. It is not clear who makes and who is made in the relation between human and machine. It is not clear what is mind and what body in machines that resolve into coding practices. In so far as we know ourselves in both formal discourse (for example, biology) and in daily practice (for example, the homework economy in the integrated circuit), we find ourselves to be cyborgs, hybrids, mosaics, chimeras. Biological organisms have become biotic systems, communications devices like others. There is no fundamental, ontological separation in our formal knowledge of machine and organism, of technical and organic. The replicant Rachel in the Ridley Scott film Blade Runner stands as the image of a cyborg culture's fear, love, and confusion ${ }^{26}$.

Segundo Haraway, a figura do ciborgue seria capaz de "abraçar construções parciais, contraditórias e permanentemente abertas ${ }^{27 " . ~ O ~ c i b o r g u e, ~}$ por sua natureza híbrida, pode "sugerir uma saída do labirinto de dualismos segundo o qual temos explicado nossos corpos e nossas ferramentas para nós mesmos ${ }^{28 "}$.

Cyborg Manifesto: Science, Technology, and Socialist-Feminism in the Late Twentieth Century in Simians, Cyborgs and Women: The Reinvention of Nature. New York: Routledge, 1991, p. 177.

\footnotetext{
${ }^{26}$ Ibidem.

${ }^{27}$ Ibid., p. 157 (Tradução minha).

${ }^{28}$ Ibid., p. 181 (Tradução minha).
} 
Para Donna Haraway, a figura do ciborgue constitui "um esforço de construir um mito político irônico ${ }^{29 " . ~}$ Ela explica que

irony is about contradictions that do not resolve into larger wholes, even dialectically, about the tension of holding incompatible things together because both or all are necessary and true. Irony is about humour and serious play. It is also a rhetorical strategy and a political method, one I would like to see more honoured within socialist-feminism. At the centre of my ironic faith, my blasphemy, is the image of the cyborg ${ }^{30}$.

O "mito do ciborgue" é a expressão teórica das indefinições figuradas em Matrix (veremos essas indefinições no próximo capítulo). No mundo do ciborgue, há espaço para tudo e a contradição é sempre bem-vinda:

a cyborg world might be about lived social and bodily realities in which people are not afraid of their joint kinship with animals and machines, not afraid of permanently partial identities and contradictory standpoints ${ }^{31}$.

\footnotetext{
${ }^{29}$ Ibid., p. 149.

${ }^{30}$ Idem.

${ }^{31}$ Ibid., p. 154
} 
A teoria do ciborgue, ao mesmo em tempo que representa uma tentativa de se pensar o mundo de maneira crítica e propor algum tipo de posicionamento político, expressa uma profunda anemia política e uma aceitação do mundo manifesta da maneira mais perversa: travestida de contestação.

A ênfase no hibridismo e na ambigüidade são estratégias que têm um potencial crítico muito limitado, uma vez que

O capitalismo é a ordem mais pluralista que a história já conheceu, sempre transgredindo limites e desmantelando oposições, misturando formas distintas de vida e sempre excedendo a medida. Toda essa pluralidade, é preciso dizer, opera dentro de limites muito rigorosos; mas isso ajuda a explicar por que alguns pós-modernistas sonham avidamente com um futuro híbrido, enquanto outros estão convencidos de que esse futuro já chegoư ${ }^{32}$.

O ciborgue é a figura exemplar de um mundo em que não se convive mais com certezas ${ }^{33}$. O "mito do ciborgue" comemora a desorientação como um promissor início:

\footnotetext{
${ }^{32}$ EAGLETON, Terry. As Ilusões do Pós-modernismo. Rio de Janeiro: Jorge Hazar, 1998. p.128-29.

33 “o espírito pós-moderno é inteiramente menos excitado do que o seu adversário moderno pela perspectiva (deixada ao estímulo do impulso de agir assim) de cercar o mundo com uma grade de categorias puras e divisões bem delineadas. Estamos também aprendendo a viver com a revelação de que não se pode articular tudo o que se sabe, e de que compreender - saber como proceder - nem sempre requer a disponibilidade de um preceito verbalizado".
} 
It is certainly true that postmodernist strategies, like my cyborg myth, subvert myriad organic wholes (for example, the poem, the primitive culture, the biological organism). In short, the certainty of what counts as nature - a source of insight and promise of innocence -- is undermined, probably fatally. The transcendent authorization of interpretation is lost, and with it the ontology grounding 'Western' epistemology. (...) From the perspective of cyborgs, freed of the need to ground politics in 'our' privileged position of the oppression that incorporates all other dominations, the innocence of the merely violated, the ground of those closer to nature, we can see powerful possibilities ${ }^{34}$.

O "mito do ciborgue" ainda se apresenta como uma alternativa política, como um esforço de criar um paradigma que, paradoxalmente, prega o fim de todos os paradigmas. A leitura do manifesto, a própria escolha desse gênero do discurso, sugerem um esforço de se pensar uma alternativa para o atual. Há, nesse esforço, uma semente de utopia.

No caso de Jean Baudrillard, o sentimento de inevitabilidade da História é bem mais agudo ${ }^{35}$. Para ele "a simulação é intransponível, inultrapassável,

(BAUMAN, Zygmunt O Mal-Estar da Pós-Modernidade. Rio de Janeiro: Jorge Zahar, 1999, p. 208).

\footnotetext{
${ }^{34}$ HARAWAY, op. cit., pp. 153-177.

${ }^{35}$ Faço a ressalva de que a obra de Baudrillard é vasta e variada. Não queremos, aqui, reduzi-la a um projeto derrotista e implicitamente conivente com as teorias do "fim da história". Baudrillard concebe o seu pessimismo como uma estratégia teórica. O que destacamos aqui é
} 
baça, sem exterioridade - nós já nem sequer passaremos 'para o outro lado do espelho', isto era ainda a idade de ouro da transcendência ${ }^{36 " .}$

Para Baudrillard, a ambigüidade é inerente ao discurso em uma época de difícil definição de posicionamentos políticos $\operatorname{claros}^{37}$. A ausência de paradigmas acaba servindo de autorização a multiplicação de discursos e de posicionamentos:

Tudo isto é verdade simultaneamente. É o segredo de um discurso que não é somente ambíguo, como o podem ser os discursos políticos, mas que traduz a impossibilidade de uma posição determinada de discurso. E esta lógica não é nem de um partido nem de outro. Ela atravessa todos os discursos independentemente da sua vontade ${ }^{38}$.

Baudrillard explora o paradoxo como categoria epistemológica, mas, diferentemente da dialética, o "modo de pensar paradoxal" celebrado por esse autor não trabalha com a idéia de síntese. Os paradoxos aqui não são etapas para o pensamento, são fins em si mesmos:

uma tendência de parte do pensamento crítico atual de se emaranhar em labirintos de paradoxos e contradição.

${ }^{36}$ BAUDRILLARD, Jean. Simulacros e Simulação, Lisboa: Relógio D’Água, 1991, p. 156.

37 "O triunfo universal do capital significa mais do que simplesmente uma derrota para todas aquelas forças outrora dispostas contra ele, embora seja isso também. Seu sentido mais profundo está no cancelamento das alternativas políticas" (ANDERSON, Perry. As origens da Pós-Modernidade. Rio de Janeiro: Jorge Zahar, 1999. p. 108).

${ }^{38}$ Ibid., p. 27. 
Para desafiar e enfrentar esse estado paradoxal das coisas, precisamos de um modo de pensar paradoxal; uma vez que o mundo ruma para o delírio, precisamos adotar um ponto de vista delirante. Não devemos mais adotar qualquer princípio de verdade, de causalidade, ou qualquer norma discursiva. Em vez disso, devemos consentir tanto a singularidade poética dos acontecimentos quanto a incerteza radical dos acontecimentos. Isto não é fáciỉ .

A obra de Baudrillard tematiza a própria indefinição. Sua postura teórica diante da indefinição é a de promotor da ininteligibilidade como categoria analítica. Para ele, "diante de um mundo que é ininteligível e problemático, nossa tarefa é clara: precisamos tornar este mundo ainda mais enigmático ${ }^{40 "}$. O paradoxo aqui aparece também no nível lingüístico, uma vez que a "tarefa clara" é precisamente a de buscar "tornar este mundo ainda mais enigmático".

Baudrillard trabalha a incerteza como componente de sua investigação teórica. Nenhuma novidade até aqui. O que torna a obra de Baudrillard relevante para entendermos a "epistemologia travada" de Matrix é a disponibilidade intelectual de se conviver com a incerteza, de manter zonas de indefinição abertas e de criar emaranhados de contradições (veremos como isso ocorre em Matrix na parte final do Capítulo 2 dessa dissertação). Sintomaticamente, nessas obras (Baudrillard e Matrix) a incerteza ganha status

\footnotetext{
${ }^{39}$ BAUDRILLARD. A Ilusão Vital. Rio de Janeiro: Civilização Brasileira, 2001. pp. 74-5. ${ }^{40}$ Ibid., p. 89.
} 
ontológico. Baudrillard explica o seu desejo teórico de "manter o mundo numa tensão enigmática":

Existe espaço para um outro tipo de pensamento? Um outro pensamento - um pensamento paradoxal que, numa inversão das palavras de Marx, proporia somente problemas insolúveis, definitivamente insolúveis? As condições materiais para a solução de tais problemas não se encontram em lugar nenhum e jamais serão encontradas. Existe lugar para um tipo de pensamento que, em vez disso, reproblematizaria todas as velhas soluções e ajudaria a manter o mundo numa tensão enigmática? Não se pode afirmar com certeza. Este pode ser o risco que o pensamento precisa correr: Ele precisa correr o risco de se tornar uma vítima de suas próprias profecias, da mesma forma como a História corre o risco de ser capturada em sua própria armadilha $^{41}$.

Esses dois exemplos da ambigüidade como matéria da teoria são sintomas do estado de desorientação política para o qual Matrix oferece uma "synthèse paroxystique ${ }^{42 " .}$

Terry Eagleton nos apresenta uma explicação cultural para o fenômeno da ambigüidade que observamos nas obras acima mencionadas:

\footnotetext{
${ }^{41}$ Ibid., p. 64.

${ }^{42}$ BAUDRILLARD, Jean. Baudrlillard decode Matrix. Le Nouvel Observateur, 19 jun. 2003.
} 
Existem outras razões para o culto da ambigüidade e da indeterminação nessas circunstâncias. Em certas nações altamente empresariais, em que se emprega o termo "agressivo" como elogio e se considera falha moral sentir-se pessimista em relação a algo, os conceitos de hesitação, negatividade, insolubilidade e congêneres podem ganhar vulto, figurando como o maior exemplo de radicalismo desde a Longa Marcha ${ }^{43}$.

No campo da política, podemos ver o "culto da ambigüidade e da indeterminação" como uma afirmação da anemia que o pensamento crítico enfrenta em meio a ausência de alternativas políticas claras:

O interesse pelo conhecimento rigoroso, determinado, diminui bastante quando uma autêntica transformação política parece fora de questão. Não há sentido em continuar trabalhando a duras penas no Museu Britânico, consumindo montes de teoria econômica indigesta, se o sistema mostra-se simplesmente inexpugnáve/ ${ }^{44}$.

A ênfase na fragmentação, no hibridismo e na indeterminação corrobora a idéia de "fim da história" e de inevitabilidade da situação atual. O hibridismo expresso pelo "mito do ciborgue" e a indeterminação da teoria de Baudrillard implicam numa impossibilidade de ver o mundo como uma totalidade de

\footnotetext{
${ }^{43}$ EAGLETON, Terry. As Ilusões do Pós-modernismo. Rio de Janeiro: Jorge Hazar, 1998. p. 14. ${ }^{44}$ Idem.
} 
relações, e conseqüentemente, numa dificuldade de engajamento em algum projeto político global $^{45}$.

Para Terry Eagleton, a opção teórica dos pós-modernistas de descrever o mundo como essencialmente fragmentado, incerto e híbrido é uma estratégia adotada para lidar com a debilidade da ação política em âmbito global. Sem uma perspectiva clara de algum projeto político mundial, esses teóricos encontram conforto na idéia de que não existe totalidade, nunca existiu, e de que a indeterminação e o hibridismo fazem parte da nossa ontologia. Segundo Eagleton,

Para os radicais, descartar a idéia de totalidade num ataque de holofobia significa, entre outras coisas mais positivas, munir-se de algum consolo muito precisado. Pois num período em que nenhuma ação política de grande projeção se afigura com efeito exeqüível, em que a assim chamada micropolítica parece a ordem do dia, soa como um alívio converter essa necessidade em virtude - persuadir-se de que as próprias limitações políticas têm, por assim dizer, uma base ontológica sólida, pelo fato de que a totalidade social resume-se afinal a uma quimera. Não importa se não existe agente político à mão para transformar o todo, uma vez

\footnotetext{
45 "Mas se, como insistem os pós-modernistas, não podemos aspirar a nenhuma representação unificada do mundo, nem retratá-lo como uma totalidade cheia de conexões e diferenciações, em vez de fragmentos em perpétua mudança, como poderíamos aspirar a agir coerentemente diante do mundo? A resposta pós-moderna simples é de que, como a representação e a ação coerentes são repressivas ou ilusórias (e, portanto, fadadas a ser autodissolventes e autoderrotantes), sequer deveríamos tentar nos engajar em algum projeto global" (HARVEY, David. A Condição Pós-Moderna. São Paulo: Edições Loyola, 2004, p. 55).
} 
que na verdade não existe um todo a ser transformado. Isto equivaleria a, tendo perdido a faca do pão, declararmos já fatiado o pão inteiro ${ }^{46}$.

Esboçamos esse panorama da teoria hoje para entendermos melhor a problemática que Matrix, enquanto objeto de análise, impõe à investigação. $\mathrm{Na}$ primeira parte desse capítulo, vimos a variedade de interpretações que Matrix suscitou. Vimos também a polissemia da figura da Matriz.

Essa polissemia constitui um obstáculo para a análise, uma vez que, ao autorizar toda sorte de interpretação, anula todas elas. A plurissignificação é característica de toda obra de arte. Obras como Dom Quixote, As mil e uma noites, A Divina Comédia, Grande Sertão: Veredas etc... suscitam interpretações diversas. Ainda assim, o horizonte de significações dessas obras é bem menos vasto que o de Matrix, na medida em que elas se inserem em contextos sócio-históricos mais facilmente rastreáveis. Enquanto objeto de análise, Matrix causa a estranha sensação de se tratar de uma obra cujo horizonte de significação se expande ad infinitum. Na próxima parte desse capítulo, tentaremos tratar desse tema e traçar uma estratégia de abordagem que dê conta do nosso objeto de estudo.

${ }^{46}$ EAGLETON, op. cit. p. 18. 


\section{Matrix como "ato socialmente simbólico"}

Neo: Is that...

Cypher: The Matrix? Yeah.

Neo: Do you always look at it encoded?

Cypher: Well, you have to. The image translators work for the construct program. But there's way too much information to decode the Matrix. You get used to it..., I don't even see the code. All I see is...blond, brunette, redhead...

O diálogo acima acontece a bordo da nave dos resistentes. O recémliberto Neo olha para os monitores da nave e vê apenas linhas de códigos verdes escorrendo pela tela. Ele é informado de que aqueles monitores mostram imagens de tudo o que ocorre dentro da Matriz.

A imagem dos monitores escorrendo códigos verdes apresenta uma boa metáfora para o trabalho de análise do próprio filme: assim como a Matriz da explicação de Cypher, Matrix, o filme, também apresenta uma quantidade imensa de informação. Mas, ao contrário dos personagens do filme, nosso trabalho aqui não deve ser o de nos conformarmos com a impossibilidade de 
ver a Matriz nitidamente e de nos acostumarmos a vê-la da maneira como ela se apresenta ao olhar.

$\mathrm{Na}$ primeira parte desse capítulo, falamos sobre a polissemia que a figura da Matriz inspira. Falamos da armadilha que essa polissemia impõe às análises do filme ${ }^{47}$.

No próximo capítulo, tentaremos responder a essa dificuldade procurando ler Matrix como sintoma, e não apenas nos limitando a buscar significados para o conteúdo manifesto do filme.

A leitura da obra como "ato socialmente simbólico ${ }^{48 "}$ nos permite escapar da polissemia (descrita no início desse capítulo) na medida em que ela considera obra e contexto histórico como algo inseparável. Tendo a história como parâmetro, inibi-se a explosão de significados que um significante aberto e polissêmico, como é o caso da figura da Matriz, pode originar.

Sobre o pluralismo de interpretações, para o qual Matrix constitui um bom exemplo, devemos considerar que

Na verdade, suspeito que só exista um número finito de possibilidades interpretativas em qualquer situação textual, e que o programa ao qual as várias ideologias contemporâneas do pluralismo se ligam de maneira passional seja extremamente negativo: a saber, impedir aquela articulação sistêmica e totalizadora dos resultados interpretativos, que só pode levar a

\footnotetext{
${ }^{47}$ Ver último parágrafo da seção "Notas sobre a complexidade do complexo".

${ }^{48}$ Cf. JAMESON, Fredric. O Inconsciente Politico: a Narrativa como Ato Socialmente Simbólico. São Paulo: Ática, 1992.
} 
embaraçosas perguntas quanto à relação entre eles e, em particular, ao lugar da História e ao fundamento último da narrativa e da produção textual ${ }^{49}$.

O ensaio "Future City" nos fornece um exemplo de abordagem para o trabalho que pretendemos realizar no segundo capítulo dessa dissertação. Nesse ensaio, Jameson investiga a idéia de "Junkspace", desenvolvida pelo arquiteto Rem Koolhaas. "Junkspace" é uma espécie de

Bermuda triangle of concepts, a petri dish abandoned: it cancels distinctions, undermines resolve, confuses intention with realization. It replaces hierarchy with accumulation, composition with addition. More and more, more is more. Junkspace is overripe and undernourishing at the same time, a colossal security blanket that covers the earth in a stranglehold of care . . Junkspace is like being condemned to a perpetual Jacuzzi with millions of your best friends . . . A fuzzy empire of blur, it fuses high and low, public and private, straight and bent, bloated and starved to offer a seamless patchwork of the permanently disjointed ${ }^{51}$.

Se tentássemos ler o Junkspace como uma figura, uma imagem, esse exercício nos levaria para muito longe e para lugar algum. Poderíamos evocar ${ }^{49}$ Ibid., p. 28-9.

\footnotetext{
50 New Left Review número 21, maio-junho de 2003. Disponível em http://newleftreview.org/?view=2449

${ }^{51}$ Idem.
} 
as mais miraculosas teorias da pós-modernidade e tratar o Junkspace como uma eloqüente afirmação do hibridismo e da incerteza.

Se, em vez disso, optarmos por estudar o Junkspace como um esforço conceitual, ainda que distorcido, de dar conta, de traduzir em termos espaciais, a complexidade das relações na era da globalização, não incorreríamos no perigo de apresentar apenas mais uma possibilidade de interpretação no democrático mercado de leituras variadas.

Diante do problema de conceitualização que a idéia de Junkspace impõe à leitura, Jameson dá um xeque-mate teórico:

I think it would be better to characterize all this in terms of History, a History that we cannot imagine except as ending, and whose future seems to be nothing but a monotonous repetition of what is already here. The problem is then how to locate radical difference; how to jumpstart the sense of history so that it begins again to transmit feeble signals of time, of otherness, of change, of Utopia. The problem to be solved is that of breaking out of the windless present of the postmodern back into real historical time, and a history made by human beings. I think this writing is a way of doing that or at least of trying to. Its science-fictionality derives from the secret method of this genre: which in the absence of a future focuses on a single baleful tendency, one that it expands and expands until the tendency itself becomes apocalyptic and explodes the world in which we are trapped into innumerable shards and atoms. The dystopian appearance is thus only the 
sharp edge inserted into the seamless Moebius strip of late capitalism, the punctum or perceptual obsession that sees one thread, any thread, through to its predictable end ${ }^{52}$.

Pretendemos, na segunda parte desse trabalho, seguir um caminho de análise semelhante, que leva a uma contextualização e a um entendimento melhor do fenômeno Matrix.

${ }^{52}$ Idem. 


\section{Hermenêutica da Máquina: da}

\section{retórica ao conceito.}

"Afortunados os tempos para os quais o céu estrelado é o mapa dos caminhos transitáveis a serem transitados, e cujos rumos a luz das estrelas ilumina. Tudo Ihes é novo e no entanto familiar, aventuroso e no entanto próprio. O mundo é vasto, e no entanto é como a própria casa, pois o fogo que arde na alma é da mesma essência que as estrelas ${ }^{53}$."

\footnotetext{
${ }^{53}$ LUKACS, Georg. A teoria do romance. São Paulo: Livraria Duas Cidades: Editora 34, 2003. p. 64.
} 


\section{A Máquina como tópos do "anticapitalismo romântico"}

O domínio da máquina sobre o homem é um pesadelo há muito imaginado e explorado pela ficção, sobretudo pela ficção-científica. Já em 1814, E.T.A. Hoffmann ajuda a esboçar os contornos desse tópos ${ }^{54}$. Em seu conto "O Homem de areia", conhecemos Olímpia, uma boneca que, dada a engenhosidade de sua construção, passa-se insuspeitadamente por uma encantadora dama da sociedade. Seu encanto apaixona Natenael, que, diante da revelação da natureza de autômato de sua amada, ensandece, ataca sua noiva humana e é morto. No trecho a seguir, vemos um registro do assombro que a idéia de autômato suscitava no tempo de Hoffmann:

...a relação de um homem vivo com figuras inertes que imitam com perfeição os movimentos e a forma do ser humano é para mim algo opressivo, sinistro, eu diria aterrador. Não posso deixar de imaginar que deve ser possível fazer com que autômatos, através de mecanismos internos ocultos, dancem com graça e agilidade, associando-Ihes homens vivos que rodopiariam com eles danças de todos os tipos, onde se veria o dançarino em carne e osso agarrar a dançarina de madeira e sair girando com

\footnotetext{
54 "O tema da máquina humana é, como se sabe, um topos da era moderna desde que, em 1748, Julien Offroy de Lamettrie definiu o homem como máquina e deu fórmula à imagem mecânica do mundo na sociedade capitalista ascendente." (KURZ, Robert, Os últimos combates. Petrópolis: Vozes, 1998, p. 382.)
} 
ela - você suportaria esta visão um minuto que fosse, sem ficar intimamente horrorizado ${ }^{55}$ ?

No conto "Maelzel's Chess-player", de 1836, Edgar Allan Poe descreve a já célebre figura do boneco turco jogador de xadrez. O conto, escrito na forma de um relato científico, simula uma investigação sobre a natureza daquele espantoso fenômeno. Todas as hipóteses que o narrador levanta para explicar o funcionamento do autômato partem da premissa de que os movimentos aparentemente autônomos do boneco jogador de xadrez são, na verdade, conduzidos por uma mão humana. A simples formulação de um mecanismo que não esteja submetido ao desígnio humano é algo abominável para o narrador do conto:

Accordingly we find everywhere men of mechanical genius, of great general acuteness, and discriminative understanding, who make no scruple in pronouncing the Automaton a pure machine, unconnected with human agency in its movements, and consequently, beyond all comparison, the most astonishing of the inventions of mankind ${ }^{56}$.

Em Matrix, reencontramos o tópos da máquina-homem, agora pintado com cores mais sombrias. Enquanto que em Poe e Hoffmann a figura do

\footnotetext{
${ }^{55}$ E.T.A Hoffmann, "O Homem de Areia" in Contos Fantásticos, Rio de Janeiro: Imago, 1993, p. 103.

${ }^{56}$ POE, Edgar Allan. Complete Stories and Poems of Edgar Allan Poe. New York: Doubleday, 1984.
} 
autômato assusta pela semelhança com o homem e pela perspectiva remota de uma agência inumana, em Matrix as máquinas adquirem vontade própria e subjugam os humanos à tirania do maquínico.

O tópos da máquina-homem não deve ser lido somente como uma especulação científico-filosófica sobre a evolução da técnica e as conseqüências disso para a humanidade. Além desse caráter especulativo, a figura da máquina propicia uma espécie de aglutinação de significados simbólicos. A máquina, como campo semântico-metafórico, pode abrigar uma série de atributos (como insensibilidade, frieza, objetividade absoluta etc...) que nomeiam simbolicamente males sociais formalmente traduzidos nessa figura distópica:

Machinery is more than a handy metaphor to describe economic process; it is the figure of the implacably objetive, referring to everything automatic, inhuman, and deathly about social life ${ }^{57}$.

A máquina como "alegoria do socialmente negativo" e já está presente em Baudelaire, como observa Walter Benjamin: "Em Baudelaire, a maquinaria se torna cifra das forças destrutivas ${ }^{58 "}$.

Em muitas narrativas distópicas, como Matrix, a figura da máquina funciona como uma espécie de "alegoria do socialmente negativo". Enquanto

${ }^{57}$ DIENST, Richard. Still life in real time: theory after television. Durham \& London: Duke University Press, 1994, p. 37.

${ }^{58}$ BENJAMIN, Walter. Charles Baudelaire: Um Lírico no Auge do Capitalismo. São Paulo: Brasiliense, 1989, p. 175. 
recurso simbólico, essa figura denota, muitas vezes, um impulso retóricocognitivo de fixar em imagem uma constelação de tensões sociais. Podemos dizer que, do ponto de vista alegórico, o tópos da máquina aspira à lucidez cognitiva da "imagem dialética"

Algumas dessas narrativas desenvolvem seu empenho crítico por meio de estruturas opositivas que tentam delinear simbolicamente alguns dos campos de tensão sociais para os quais a obra (entendida como "ato socialmente simbólico ${ }^{60 ")}$ projeta-se como resposta.

Quando ficcionalmente bem realizadas, essas estruturas opositivas, vistas como formulações simbólicas, operam uma tentativa de "mapeamento cognitivo", agrupando, de um lado, o que o inconsciente coletivo concebe como males sociais a serem combatidos e, de outro, o que é visto como remédio para esses males.

Um exame atento de algumas dessas estruturas opositivas pode, no entanto, revelar impasses muitas vezes escondidos sob a superficial clareza da divisão proposta. O ensaio "Aldous Huxley e a Utopia”, em que Adorno estuda o romance Admirável Mundo Novo, é paradigmático no que diz respeito ao desvendamento dessas estruturas opositivas. Ainda nesse capítulo, partiremos desse exemplo de análise para tentarmos entender como as antinomias podem, muitas vezes, referendar aquilo que originalmente é objeto de crítica e

\footnotetext{
${ }^{59}$ Conceito que Walter Benjamin elaborou para definir certas imagens que carregam enorme potencial cognitivo. Na tese XVII das suas Teses sobre o Conceito de História, Benjamin explica que, na imagem dialética, "o pensamento se detém repentinamente numa constelação saturada de tensões". (LOWY, Michael. Walter Benjamin: aviso de incêndio, Uma leitura das teses “Sobre o conceito de história”. São Paulo: Boitempo, 2005, p. 130).

${ }^{60} \mathrm{O}$ conceito de "ato socialmente simbólico" é desenvolvido por Fredric Jameson em várias de suas obras, sobretudo no livro $O$ Inconsciente Político: a narrativa como ato socialmente simbólico. São Paulo: Ática, 1992.
} 
como elas podem ser lidas como sintomas de impasses do pensamento crítico. Logo, retomaremos esse assunto. Por hora, tentaremos fazer um breve levantamento histórico da ocorrência de algumas dessas estruturas opositivas. Faremos isso com a intenção de historicizar as oposições que estudaremos em Matrix, considerando, para tanto, a inserção dessas dicotomias no contexto mais amplo do "anticapitalismo romântico".

O conceito de "anticapitalismo romântico" foi desenvolvido por Michael Lowy, a partir da formulação inicial de Georg Lukács. Em seu livro "Romantismo e Messianismo", Lowy esclarece que

o anticapitalismo romântico nasceu na segunda metade do século XVIII, mas não deixou, até hoje, de ser um componente essencial da cultura moderna. O que é usualmente designado como o movimento romântico na arte e na literatura, situado principalmente no início do século XIX, é apenas uma de suas múltiplas e extremamente variadas manifestações. Como Weltanschauung, isto é, uma abrangente visão de mundo, um estilo de pensamento, uma estrutura básica de sentimento, pode ser encontrado não apenas no trabalho de poetas e escritores de imaginação e de fantasia como Novalis, E.T.A. Hoffmann e os surrealistas, mas também nos romances dos realistas, como Balzac, Dickens e Thomas Mann; não apenas entre artistas como Delacroix ou os pintores pré-rafaelitas, mas também entre 
economistas políticos como Sismondi, ou sociólogos como Tonnies $^{61}$.

No universo das artes, as manifestações do "anticapitalismo romântico" caracterizam-se, basicamente, pela

nostalgia das sociedades pré-capitalistas e uma crítica ético-social ou cultural ao capitalismo (...) Na visão romântica do mundo, esse passado pré-capitalista se encontra ornado de uma série de virtudes (reais, parcialmente reais ou imaginárias) como, por exemplo, a predominância de valores qualitativos (valores de uso ou valores éticos, estéticos, e religiosos), a comunidade orgânica entre os indivíduos, ou ainda, o papel essencial das ligações afetivas e dos sentimentos - em contraposição à civilização moderna, fundada na quantidade, o preço, o dinheiro, a mercadoria, o cálculo racional e frio do lucro, a atomização egoística dos indivíduos ${ }^{62}$.

A fixação do protesto em termos antinômicos é uma característica marcante de muitas obras que integram o quadro do "anticapitalismo romântico". Segundo Lowy, já no final do século XIX, os românticos e os neoromânticos germânicos

\footnotetext{
${ }^{61}$ LOWY, Michel. Romantismo e messianismo. São Paulo: Perspectiva, 1990, p. 37. ${ }^{62}$ Ibid., p.13-14.
} 
criticaram a Zivilisation - o progresso material sem alma, ligado ao desenvolvimento técnico e científico, a racionalidade burocrática, a quantificação da vida social - em nome da Kultur, o corpo orgânico dos valores morais, culturais, religiosos e sociais ${ }^{63}$.

Em termos Hegelianos, essas obras estabelecem uma dicotomia baseada na oposição entre o "espírito objetivo" (as relações sociais, o direito, o Estado etc.) e o "espírito absoluto" (a filosofia, a arte, a religião) ${ }^{64}$.

A divisão entre Kultur e Zivilisation, e a eleição da primeira como remédio e salvação contra a segunda, aparece, freqüentemente, na obra de Românticos como William Wordsworth, Samuel Taylor Coleridge, Mathew Arnold, Friedrich Schiller, entre outros. Em vários momentos da obra desses autores, é possível observar uma defesa da Arte como espaço de sublimação dos males e das limitações que um mundo dominado por valores quantitativos e pragmáticos impõe às almas:

A arte é filha da liberdade e quer ser legislada pela necessidade do espírito, não pela privação da matéria. Hoje, porém, a privação impera e curva em seu jugo tirânico a humanidade decaída. A utilidade é o grande ídolo do tempo; quer ser servida por todas as forças e cultuada por todos os talentos. Nessa balança grosseira, o mérito espiritual da arte nada pesa, e

\footnotetext{
${ }^{63}$ Ibid., p. 206.

${ }^{64} C f$. Lowy, op. cit., p. 28.
} 
ela, roubada de todo estímulo, desaparece do ruidoso mercado do século ${ }^{65}$.

Na obra de William Blake, podemos ver uma das possíveis formulações do "anticapitalismo romântico". Na sua poesia, nota-se um impulso mitológico que pode ser lido como uma espécie de estratégia simbólica para insuflar um arpejo de "re-encantamento do mundo". Das figuras criadas por Blake, Urizen (personificação da razão repressiva e autoritária) e Los (que representa a imaginação, a arte e a poesia) simbolizam as duas faces da oposição entre Zivilisation e Kultur.

Também Charles Dickens, em seu romance "Hard Times", expõe uma confiança romântica em

Sensibilidades, afeições, fraquezas... desafiando todos os cálculos jamais feitos pelo homem, e não mais conhecidos à sua aritmética do que o é o seu Criador. Em Hard Times, vemos a crença nas "essências sutis de humanidade que podem eludir a extrema astúcia da álgebra até que o eco da última trombeta leve até mesmo a álgebra à ruína ${ }^{66}$.

Podemos observar semelhante busca de transcendência no romance "Holy Fire", do escritor cyberpunk Bruce Sterling. Nesse romance, vemos o mundo dominado por uma indústria farmacêutica onipotente, que prolonga a

\footnotetext{
${ }^{65}$ SCHILLER, Friedrich. A Educação Estética do Homem. São Paulo: Iluminuras, 1989, p. 22.

${ }^{66}$ LOWY, op. cit., p. 38.
} 
vida das pessoas para além dos limites da natureza. Os indivíduos que se submetem aos procedimentos os quais garantem a extensão da vida são chamados de "pós-humanos". Essas pessoas pagam pelo prolongamento de suas vidas com uma dependência permanente em relação ao conglomerado médico-industrial que Ihes proporcionou esse "benefício". O tal "holy fire" do título do romance é concebido como um espaço de transcendência dessa realidade "pós-humana" (termo exaustivamente repetido no romance) e de reencontro do individuo com sua natureza roubada. Temos um testemunho do apelo por transcendência, que permeia essa obra, no seguinte trecho: "Podemos atirar termos médicos contra a alma, mas não podemos aprisioná$1 a^{\prime \prime 67}$.

Tendo o "anticapitalismo romântico" como um amplo quadro epistemológico, vimos, até aqui, algumas manifestações desse tipo de elaboração crítica. Dentre os tópoi que carregam a rejeição à sociedade capitalista como bandeira, temos a máquina como uma presença marcante na ficção contemporânea.

A figura da máquina, como pólo agregador de atributos negativos, freqüentemente é requisitada para assumir metaforicamente os aspectos atribuídos ao lado Zivilisation das antinomias que encontramos em Matrix e em obras semelhantes.

Em Matrix, o conflito homem/máquina pode ser visto no conteúdo manifesto do enredo: há uma guerra em curso, em que o prêmio é a sobrevivência. O histórico desse conflito é relatado pelo personagem Morfeu, quando este explica ao recém libertado Neo a origem da Matriz. Segundo

${ }^{67}$ STERLING, Bruce. Holy fire. Nova York: Bantam Books, 1996, p. 68. 
Morfeu, em algum momento da história (os humanos sobreviventes não sabem precisar quando), o homem "celebrou a sua genialidade" criando a Inteligência Artificial. Esse tipo de máquina contava com a capacidade de se reproduzir. Em determinado momento, um dos lados iniciou um ataque (não se sabe se foi o homem ou se foram as máquinas). Em um ato de desespero, o homem encobriu os céus com um manto negro de fumaça, na tentativa de privar as máquinas de sua fonte de energia mais abundante: o sol. As máquinas, no entanto, encontraram uma fonte de energia alternativa e renovável: o homem. Posto o conflito, o filme se desenrola na expectativa da vitória dos humanos sobre as máquinas.

A partir desse conflito, esboça-se, na narrativa, uma oposição entre homens e máquinas. Uma dicotomia entre valores matérias e espirituais (nos moldes das manifestações do "anticapitalismo romântico") vai se delineando. Encontramos um indício dessa oposição na fala do personagem Mouse, o adolescente da equipe de Morfeu que gasta seu tempo livre aperfeiçoando a sua "Mulher de Vestido Vermelho". Em conversa com Neo, Mouse filosofa: "negar os nossos impulsos é negar a própria matéria da nossa humanidade ${ }^{68 "}$. Contra a objetividade da máquina, se posta a libido, a ato gratuito da satisfação pela satisfação: Eros versus Civilização.

\footnotetext{
${ }^{68}$ Esse é o diálogo original: Dozer: It's a single celled protein combined with synthetic aminos, vitamins, and minerals. Everything the body needs / Mouse: It doesn't have everything the body needs. [He turns to Neo, who is fiddling with his food, picking it up with his spoon and dropping it back into the bowl] / Mouse: So I understand you've run through the agent training program...you, uh, you know...I wrote that program. / Switch rolls her eyes / Apoc: Here it comes... / Mouse: So, uh, what did you think of her? / Neo: Of who...? / Mouse: The woman in the red dress! I, I designed her. She, um..well she doesn't talk very much, but...but if you'd like to meet her, I can arrange a much more personalized milieu. / Switch: Digital pimp, hard at work. Mouse: Pay no attention these hypocrites, Neo. To deny our own impulses, is to deny the very thing that makes us human.
} 
Nessa ênfase nos impulsos como resposta à desumanização do mundo, temos o reconhecimento implícito de que o progresso traz consigo a repressão dos instintos naturais do homem. Na "Dialética do Esclarecimento" ${ }^{69 ", ~ e s s a ~ i d e ́ i a ~}$ é discutida a partir da passagem da Odisséia ${ }^{70}$ em que Ulisses, acatando um conselho de Circe $^{71}$, faz-se acorrentar para poder provar, impunemente, do encanto fatal das sereias. Com esse ato, Ulisses reprime o impulso em nome do conhecimento (que se opõe ao mito, às forças arcaicas). Para Olgária Matos, "do ponto de vista da Dialektik [Dialética do Esclarecimento], a contrapartida da conquista da natureza é a repressão, a 'desnaturalização do homem, ${ }^{72,}$

Antes de prosseguirmos, é preciso que contextualizemos a frase do personagem Mouse. Ela é dita quando Mouse, em diálogo com Neo, ofereceIhe um encontro virtual com a "Mulher de Vestido Vermelho", sua criação. Portanto, o impulso a que ele se refere é o impulso da satisfação sexual, que é colocado, no contexto do filme, como um objeto de resistência humana. $\mathrm{O}$ mesmo impulso é retomado, em Matrix Reloaded, na grande rave na caverna que ocorre, não por coincidência, após um discurso em que Morfeu urge a multidão a resistir contra as máquinas. Essa seqüência, que é intercalada com cenas em que Neo e Trinity aparecem fazendo sexo, investe pesadamente na jouissance, dispondo de muitos corpos, sons, luzes, cores, movimentos rápidos

\footnotetext{
${ }^{69}$ ADORNO, Theodor W; HORKHEIMER, Max. Dialética do esclarecimento: fragmentos filosóficos. Rio de Janeiro: Zahar, 1986.

${ }^{70}$ Canto XII, vv. 37-54.

${ }^{71}$ (Odisséia, XII, vv. 37-54).

${ }^{72}$ MATOS, Olgária Chain Feres. Os arcanos do inteiramente outro. São Paulo: Brasiliense, 1995.
} 
da câmera intercalados com movimentos lentos e panorâmicas, e muita percussão. O alto teor sinestésico dessa seqüência compõe o sentido de afirmação do impulso e, por extensão, do humano, que é também sugerido pela atmosfera erótica das cenas.

Essas duas passagens funcionam como uma espécie de afirmação do estritamente humano frente à dominação do maquínico. Elas apostam no impulso (sexual, no caso) como elemento inegavelmente humano, como espaço de libertação e resistência. No entanto, é preciso considerar que,

a partir da realidade tecnológica, o espaço de Eros se contrai, intensificando-se a sexualidade. Em outras palavras, libera-se a sexualidade, o impulso parcial de Eros, e a vida é, em grande medida, deserotizada. (...) A liberação sexual é aparente porque segue um modelo imposto de organização sexual, que impõe a centralização da sexualidade, isto é, a primazia da genitalidade, da procriação e a unificação dos objetos libidinais em um único objeto do sexo oposto ${ }^{73}$.

Para Herbert Marcuse, a sexualidade é um "impulso parcial 'especializado"74". Assim,

A liberalização sexual consentida pela sociedade

\footnotetext{
${ }^{73}$ CAMPOS, Maria Teresa Cardoso de. Marcuse: realidade e utopia. São Paulo: Annablume, 2004. pp. 46-47.

${ }^{74}$ Ibid., p. 46.
} 
industrial contemporânea é, portanto, um dos disfarces da dominação. A liberdade sexual, segundo Marcuse, é mais um dos instrumentos de repressão, agindo em prol da coesão social. Ele diz que "esta sociedade transforma tudo o que toca em fonte potencial de progresso e de exploração, de servidão e satisfação, de liberdade e de opressão. A sexualidade não constitui exceção"75.

Por trás de uma aparência de negação da realidade opressiva, essa ênfase nos impulsos meramente sexuais pode funcionar como elemento de reafirmação do estado de dominação inicialmente criticado. O que Mouse oferece a Neo é a satisfação de um impulso físico, a única coisa que o autômato "Mulher de Vestido Vermelho", mero dispositivo de satisfação sexual, pode oferecer. Nesse caso,

ao invés da sublimação, tem lugar a dessublimação, que significa, de acordo com Marcuse, a substituição da satisfação mediata da sublimação por satisfação imediata ${ }^{76}$.

Além dos impulsos, temos, no enredo de Matrix, o Amor como elemento de distinção do humano frente ao maquínico. Há, nos filmes, vários pares românticos (Link e Zee; Morfeus e Niobe; Lock e Niobe; Neo e Trinity). Fatos importantes do enredo são determinados pela presença do Amor, como a

\footnotetext{
${ }^{75}$ Idem.

${ }^{76}$ Idem.
} 
ressurreição de Neo no primeiro filme. Atingido por vários tiros, Neo é resgatado do reino dos mortos pelo amor de Trinity. Em outro momento importante da narrativa, Zee, esposa de Link (operador da nave Nabucodonosor) se arrisca para abrir os portões de Zion e, com isso, permitir que a nave de seu marido entre na cidade e acabe com todas as máquinas que lá se encontram ${ }^{77}$. Parece claro, no filme, que a dedicação quase suicida de Zee na guerra é justificada mais pela vontade de salvar o seu amor, Link, do que pela determinação de ajudar os humanos na luta contra as máquinas ${ }^{78}$. Fato semelhante ocorre quando Neo é obrigado a escolher entre a salvação da humanidade e a vida de Trinity. Esse dilema do Escolhido é revelado pelo Arquiteto, que, depois de dissertar sobre as fraquezas humanas, prevê a escolha de $\mathrm{Neo}^{79}$.

${ }^{77}$ Esse episódio ocorre ao final de "Matrix Revolutions".

${ }^{78}$ A intenção de Zee é revelada nesse diálogo: Cas: Zee, what are you doing? / Zee: Making shells. / Cas: They're evacuating our level. We have to go. / Zee: I'm not going with you. / Cas: What? / Zee: They've called for volunteers to hold the dock. / Cas: Kids, you stay here. [to Zee] I know how you feel, Zee, but you can't do that. / Zee: I have to. / Cas: Why? / Zee: Because I love him. I love him the same as he loves me. And if I were out there and he were here, I know he would be doing the same thing. / Cas: But you're gonna get yourself killed. It's crazy, Zee. I Zee: Maybe it is. But ask yourself, if it were Dozer, and you knew the only chance you had to see him again was to hold the dock, what would you do? / Cas: Make shells.

${ }^{79} \mathrm{O}$ encontro de Neo com o Arquiteto acontece em "Matrix Reloaded": Architect: However, the relevant issue is whether or not you are ready to accept the responsibility of the death of every human being on this world. It is interesting, reading your reactions. Your 5 predecessors were, by design, based on a similar predication - a contingent affirmation that was meant to create a profound attachment to the rest of your species, facilitating the function of the One. While the others experienced this in a very general way, your experience is far more specific vis a vis love / Neo: Trinity / Architect: Apropos, she entered the Matrix to save your life, at the cost of her own / Neo: No / Architect: Which brings us at last to the moment of truth, wherein the fundamental flaw is ultimately expressed, and the anomaly revealed as both beginning and end. There are two doors. The door to your right leads to the Source, and the salvation of Zion. The door to your left leads back to the Matrix, to her and to the end of your species. As you adequately put, the problem is choice. But we already know what you are going to do, don't we? Already, I can see the chain reaction - the chemical precursors that signal the onset of an emotion, designed specifically to overwhelm logic and reason - an emotion that is already blinding you from the simple and obvious truth. She is going to die, and there is nothing you can do to stop it. 
"Matrix Reloaded" começa com Neo preso em um espaço entre os dois mundos (a Matriz e o mundo real). Só o personagem "o Homem do trem" pode resgatar Neo, mas esse personagem trabalha para o Merovíngio (o francês). Trinity, Morfeu e Serafim (o guarda-costas da Oráculo) vão até o Merovíngio para tentar convencê-lo a ajudar Neo. Diante da recusa do francês em libertar o Escolhido, Trinity, desarmada, enfrenta vários capangas e consegue dominar a situação, apontando uma arma, que ela consegue recolher em meio à confusão da luta, para a cabeça do Merovíngio. Diante da ameaça de Trinity, Merovíngio hesita em ceder, mas é convencido por Perséfone, sua esposa, a qual argumenta que o amor de Trinity por Neo faria com que ela não hesitasse um só instante em matar todos ali, se preciso fosse. Diante da observação de sua esposa, Merovíngio reflete e comenta que o padrão de comportamento das pessoas tomadas pelo amor é semelhante ao padrão da insanidade.

Contra a objetividade do cálculo, contra a eficiência da máquina, colocase o sentimento, a insanidade e a espontaneidade. Isso aparece nas falas acima reproduzidas de Merovíngio e do Arquiteto. O amor constitui, assim, um elemento simbólico importante para compor o campo da resistência humana dentro da oposição estabelecida entre homem e máquina.

Como figura retórica, o amor é associado a atributos como a loucura, a espontaneidade, a poesia etc... contrários à rigidez e a objetividade do universo pragmático do capital ${ }^{80}$.

${ }^{80} \mathrm{O}$ caráter anti-mercantilista desse sentimento é reivindicado, por exemplo, nesses versos de Drummond: $O$ beijo ainda é um sinal, perdido embora, / da ausência de comércio, / boiando em tempos sujos (ANDRADE, Carlos Drummond de. Nova Reunião: 19 livros de poesia. Rio de Janeiro: José Olympio, 1987, p. 110). 
A aposta no Amor como elemento de resistência do estritamente humano filia-se à tradição do "anticapitalismo romântico" na medida em que procura nesse sentimento um espaço livre da "racionalidade tecnológica ${ }^{81 ":}$

Todos os elementos dissonantes numa sociedade passiva, inerte e sem reação - como a família, o indivíduo, o amor devem ser reivindicados, reabilitados contra o totalitarismo da sociedade unidimensional. Para Adorno, no amor os amantes se entregam um ao outro sem cálculo ou interesse, sem dominação ${ }^{82}$.

Numa sociedade totalmente racionalizada, onde tudo é regido pelo imperativo da utilidade, não há grandes espaços para efusões sentimentais. Assim ocorre no Admirável Mundo Novo de Aldous Huxley, onde as pessoas são instruídas desde pequenas a praticarem sexo apenas por diversão, sem conseqüências afetivas, potencialmente perigosas para a produtividade dos indivíduos. No mundo imaginado por Huxley,

a ataraxia protoburguesa englobou finalmente toda $e$ qualquer reação. Ao atingir o Eros, a ataraxia volta-se imediatamente contra o que antes era tido como o bem supremo, a eudemonia subjetiva, em razão da qual se exigia a purificação

\footnotetext{
${ }^{81}$ Cf. MARCUSE, Herbert. Eros e Civilização. Rio de Janeiro: Zahar, 1968.

${ }^{82}$ MATOS, Olgária. A escola de Frankfurt: luzes e sombras do iluminismo. São Paulo: Moderna, 2003, p. 55.
} 
dos afetos. Ao atacar o êxtase, ela ataca ao mesmo tempo o núcleo de qualquer relação entre seres humanos, a tentativa de escapar à existência monadológica ${ }^{83}$.

Essa ênfase no humano funciona no filme, alegoricamente, como ponto de partida para a delimitação de uma zona mínima de autonomia, em que o homem se veja livre da racionalidade dominante. Em um mundo em que a autonomia é cada vez menor, a imaginação encontra dificuldades de pensar espaços para o exercício da liberdade, e essa dicotomia, nem sempre bem definida, entre o espiritual e o material, que podemos encontrar em muitas obras ficcionais, pode ser vista como a expressão artística dessa busca.

Até aqui, vimos como algumas obras constroem alegoricamente oposições que dão forma a conflitos da experiência social. Introduzimos o conceito de "anticapitalismo romântico" e, a partir desse conceito, tentamos inserir o tópos da máquina no conjunto das manifestações anticapitalistas em ficção.

Sem dúvida, o conceito de "anticapitalismo romântico" ajuda-nos a compreender o significado histórico de uma série de movimentos artísticos, como o Romantismo, o Surrealismo, o expressionismo etc... Ajuda-nos, também, a entender a recorrência de figuras como o tópos da máquina, e a pensarmos essas figuras numa perspectiva histórica mais ampla.

Como elemento retórico, o tópos da máquina traz associações imediatas. Isso acontece devido à fixação de certos atributos (frieza, calculismo, objetividade, insensibilidade etc...) como constitutivos dessa figura.

${ }^{83}$ ADORNO, Theodor W. Prismas : crítica cultural e sociedade. São Paulo: Ática, 1998, p. 99. 
Ainda do ponto de vista retórico, podemos dizer que, em Matrix, o tópos da máquina participa da construção ficcional carregando consigo os atributos associados a essa figura. Lendo alegoricamente a recorrência desse tópos, temos que ele, geralmente, funciona como peça chave para a construção de uma crítica a certos aspectos da sociedade capitalista. Como resposta simbólica à degradação do mundo, o tópos da máquina filia-se às obras do "anticapitalismo romântico", uma vez que a máquina é parte indissociável da modernização capitalista e congrega várias características associadas ao modo de vida sob esse regime econômico-social ${ }^{84}$. De certa maneira, condenar a máquina é, ainda que ingenuamente, uma maneira de criticar o modo de produção capitalista.

A máquina é um elemento ausente das sociedades antigas. Recusá-la também significa evocar uma experiência social diferente da nossa. Dessa forma, o tópos aqui estudado é melhor entendido quando visto como parte de uma tendência crítica historicamente delineada. Essa inserção histórica é necessária para que estudemos a presença da máquina em Matrix como um registro simbólico altamente saturado de pulsões sociais. A máquina, como veremos mais adiante, é uma alegoria chave para pensarmos o mundo hoje.

\footnotetext{
84 "Under capitalismo, the worker and the machine enter into irreversible relations of reciprocal constitution. Both become 'effects'of capital, operating on the same plane as 'value as such" (DIENST, Richard. Still life in real time: theory after television. Durham \& London: Duke University Press, 1994. p. 47). A canônica cena do filme "Tempos Modernos" em que Carlitos é engolido pelas engrenagens da máquina é expressiva da relação acima mencionada.
} 


\section{O Admirável Mundo Novo de Matrix}

Nessa parte do nosso estudo, veremos, a partir da leitura que Adorno faz de Admirável Mundo Novo, como construções ficcionais organizadas em torno de dicotomias podem revelar dilemas e contradições da vida social.

Pesadelos ficcionais como Matrix e Admirável Mundo Novo tentam projetar no futuro uma crítica do presente. Esse futuro hipotético representa uma especulação sobre os desdobramentos dos males sociais contemporâneos, mapeados pela obra. Tomar essas obras como pré-visões do futuro tornaria a análise um exercício de premonição muito abstrato para ter alguma relevância crítica. Em vez disso, podemos estudar esses futuros imaginados como construções simbólicas altamente expressivas dos dilemas e contradições marcantes no momento histórico em que essas obras foram concebidas. Além disso, o exercício ficcional de imaginar o futuro pode proporcionar imagens que possibilitem a consciência "dos horizontes ou limites externos daquilo que pode ser pensado e imaginado em nosso presente" ${ }^{135}$.

Adorno observa que Admirável Mundo Novo foi escrito sob o impacto do encontro do intelectual exilado Aldous Huxley com a sociedade americana. Esse romance expressa um "olhar de pânico ${ }^{86 "}$ do intelectual que é lançado à arena principal do capitalismo selvagem. Sobre o contexto de produção do romance, Adorno observa que

\footnotetext{
${ }^{85}$ JAMESON, Fredic. Utopian Studies: Journal Of The Society for Utopian Studies, Volume 9, No. 2, 1998, p. 61. (tradução minha)

${ }^{86}$ ADORNO, op. cit., p. 93.
} 
impotente na maquinaria das relações mercantis que se desenvolvem por todos os lados e se tornam o único parâmetro, o intelectual reage ao choque com pânico. O "Brave New World" de Huxley é o sedimento desse pânico, ou melhor, sua racionalização ${ }^{87}$.

No caso do intelectual Aldous Huxley, o choque proporcionado pelo contato com a sociedade americana gerou uma construção ficcional radicalmente distópica. $O$ protesto de Huxley se manifesta em forma de oposições entre o que é repudiado como males da sociedade capitalista e o que é visto como espaço de resistência a essa sociedade. Assim,

Huxley constrói reificação e humanidade em uma oposição rígida, seguindo a tradição romanesca que trata do conflito entre o homem vivo e as relações petrificadas ${ }^{88}$.

No romance de Huxley, os atributos positivos do protesto "anticapitalista romântico" são encarnados pelo personagem Selvagem. Tendo sido criado fora da sociedade do "Mundo Novo", o Selvagem funciona na narrativa como elemento de estranhamento àquele mundo. Ele é, assim, dotado de uma vantagem epistemológica em relação aos habitantes da cidade, uma vez que,

\footnotetext{
${ }^{87}$ Ibid., p. 92.

${ }^{88}$ Ibid., p. 102.
} 
não sendo cria dessa sociedade, ele não sofreu 0 processo de "condicionamento" a que todos os habitantes da cidade são submetidos desde o nascimento. Enquanto recurso narrativo, o Selvagem permite que o narrador implícito teça uma série de comentários sobre aquela sociedade. Muitos desses questionamentos são feitos pelo próprio Selvagem. A presença desse personagem no romance acentua o processo de reificação mencionado acima por Adorno. O Selvagem, representante da Kultur, lê Shakespeare, recusa-se à submissão ao "soma" (entorpecente institucionalizado e amplamente utilizado como medida de profilaxia social) e hesita em ter qualquer relação íntima com Lenina, sua amada, optando pelo idealismo do amor platônico. Essa ênfase na transcendência, cujos esboços podemos perceber também em Matrix, hipostasia

sem cerimônia o espírito diante da prática e da satisfação das necessidades materiais. Como, entretanto, todo espírito deve seu sentido ao processo vital da sociedade e sobretudo à divisão social do trabalho, e como todo espiritual, na busca de seu "preenchimento", relaciona-se com o existente, sendo implicitamente também uma indicação à práxis, assim, quando o espírito e as necessidades materiais são colocados em uma oposição incondicionada e eterna, perpetua-se ideologicamente uma situação de divisão do trabalho e de cisão da sociedade ${ }^{89}$.

${ }^{89}$ Ibid., p.104. 
Quando o protesto anticapitalista se dá pela exaltação do Amor, dos Impulsos, da Espontaneidade, da Alma, da Arte etc... corre-se o risco de, pela fixação desses atributos humanos como coisas absolutamente livres da contaminação do mundo, obter-se efeito contrário ao almejado, ou seja, em nome da crítica da racionalidade dominante, reforçar ainda mais o processo de reificação contra o qual esses atributos foram inicialmente evocados. Assim, a tentativa de separar o Amor do mundo degradado não ajuda a combater a fonte da degradação, mas reforça o processo de objetificação de todas as coisas, processo que está na base da degradação criticada. Adorno identifica essa contradição no romance de Huxley:

a desgraça do presente não é o predomínio da chamada cultura material sobre a espiritual (...) O que deveria ser atacado é a separação, ditada socialmente, entre a consciência e sua realização social, uma realização que consistiria na própria essência da consciência. Exatamente o chorismus entre $o$ espiritual e o material, instituído pela philosophia perennis de Huxley, a substituição da 'faith in happiness' por um indefinido 'goal somewhere beyond', reforça a situação reificada, cujos sintomas Huxley não pode tolerar: a neutralização de uma cultura que se separa do processo real de produção ${ }^{90}$.

Diferentemente do que ocorre no livro de Huxley, em Matrix a dicotomia entre Kultur e Zivilisation, ou entre o espiritual e o material, é bem mais sutil.

${ }^{90}$ Ibid., p. 105. 
Por vezes, ela é ofuscada pela cacofonia de temas que são endereçados nos filmes. No entanto, podemos vislumbrar em Matrix contradições semelhantes àquelas que Adorno aponta no pensamento dicotômico com que a crítica do atual é tecida no romance Admirável Mundo Novo.

A figura da Matriz é uma eloqüente alegoria da reificação. Totalmente despojadas de sua consciência, as pessoas têm sua energia escravizada pela Matriz. As metáforas da "plantação" de humanos e da pilha (os humanos ainda presos à Matriz são chamados de "coppertop", pilha, em inglês) atestam o estado de escravização a que as pessoas, aprisionadas a Matriz, estão submetidas. Aqui, temos o que Slavoj Zizek chama de o "impasse libidinal" da Matriz enquanto dispositivo:

Por que a Matriz precisa de energia humana? A solução puramente energética é, obviamente, sem sentido. A Matriz poderia facilmente ter encontrado outra fonte de energia mais confiável, que não teria exigido o arranjo extremamente complexo da realidade virtual, coordenado para milhões de unidades humanas ${ }^{91}$.

O próprio Zizek responde, dizendo que "a única resposta consistente é que a Matriz se alimenta da jouissance dos seres humanos ${ }^{92 " . ~ A ~ i m a g e m ~ d e ~}$ seres humanos tendo sua energia vital totalmente colonizada pela máquina encerra uma radical nota de pessimismo sobre a situação do mundo hoje. A

\footnotetext{
${ }^{91}$ ZIZEK, Slavoj. Matrix: ou os Dois Lados da Perversão In IRWIN, William (Org). Matrix: Bem-Vindo ao Deserto do Real. São Paulo: Madras, 2003. p. 281.

${ }^{92}$ Idem.
} 
imagem da Matriz figura uma dominação perversamente eficaz, uma vez que os dominados não têm sequer consciência de seu estado de escravidão, como é explicitado no seguinte diálogo:

Morfeu: The Matrix is everywhere. It's all around us, even in this very room. You can see it when you look out your window or when you turn on your television. You can feel it when you go to work, when you go to church, when you pay your taxes. It is the world that has been pulled over your eyes, to blind you from the truth.

Neo: What truth?

Mofeu: That you are a slave, Neo. Like everyone else, you were born into bondage, born into a prison that you cannot smell or taste or touch. A prison...for your mind....

Podemos dizer que Neo e os humanos que lutam contra as máquinas em Matrix estão em situação semelhante à do Selvagem do romance de Huxley. Em ambos os casos, observamos uma profunda rejeição da situação hegemônica e um anseio por uma ruptura. O Selvagem de Admirável Mundo Novo tenta escapar da civilização vivendo em um local isolado, fora da cidade. Em Matrix, os humanos que chegam a ter consciência da sua condição de escravo fogem da ilusão da Matriz, com o auxílio da resistência, e buscam abrigo em Sião.

Matrix e "Admirável Mundo Novo" contam histórias de ruptura, figuram um desejo de escapar de um mundo sufocantemente hegemônico. Raymond 
Williams identifica uma mudança nas narrativas utópicas do paradigma da transformação para o paradigma da fuga, da ruptura ("getaway, breakway”):

Variability and autonomy, within the generally harmonious condition, are indeed among the primary utopian features. But now, under the pressures of consumer capitalism and of monopoly socialism, the mode has broken. As in the later stages of realist fiction, self-realization and self-fulfilment are not to be found in relationship or in society, but in breakaway, in escape: the path the Savage takes, like a thousand heroes of late-realist fiction, getting out from under the old place, the old family, or like a thousand science-fiction heroes, running to the wastes to escape the machine, the city, the system. ${ }^{93}$

\section{A "Alegoria da desconexão" e o paradoxo da autonomia}

\section{sem escolha}

O ceticismo em relação a uma possível "desconexão" com o mundo capitalista domina o pensamento atual. Pensá-la implica, de antemão, uma luta contra o ceticismo dominante. As teses sobre o "fim da história", mesmo

${ }^{93}$ WILLIAMS, Raymond. Problems in materialism and culture. London: Verso, 1980, pp. 2067. 
quando rejeitadas, constituem um obstáculo do qual o pensamento emancipatório não deve se esquivar.

Esse quadro desolador deve antes atiçar a chama da utopia do que alimentar o incêndio da resignação. Qualquer tentativa de se pensar uma "ruptura ontológica" com o atual já tem o mérito de afirmar um profundo descontentamento com o presente.

A aceitação do caráter irreversível da situação atual, mesmo quando feita em nome de uma estratégia teórica que privilegie o ceticismo como arma, implica em uma aceitação do atual. Uma vez que a idéia da irreversibilidade é dominante, a aprovação (ainda que como ceticismo estratégico) de tal opinião torna-se mais um lamento irônico do que um começo de revolta. Além disso, "o pensamento que não deixa saída alguma já implica de antemão a liquidação de tudo o que não é assimilado ${ }^{94 "}$.

No atual cenário de ceticismo, qualquer objeto que apresente indícios de um desejo de ruptura com o pensamento hegemônico merece atenção crítica. Podemos observar, em Matrix, a figuração de uma "estrutura de sentimentos" da ruptura com o atual. Nesses filmes, temos o que poderíamos chamar, seguindo Jameson, de "alegoria da 'desconexão ${ }^{95 "}$.

Uma das imagens mais significativas de Matrix é, sem dúvida, as cenas em que vemos milhares de corpos humanos sendo usados como baterias. As

\footnotetext{
${ }^{94}$ ADORNO, op. cit., p. 111.

95 "Mas parece claro que a maior barreira a qualquer tipo de política de controle da tecnologia é justamente a nossa mais profunda crença (verdadeira ou falsa) de que a inovação tecnológica é irreversível. Isso pode então ser visto como uma alegoria da "desconexão" no nível do político: tentar imaginar uma comunidade sem computadores - ou carros ou aviões - é tentar conceber a viabilidade de se separar do global." (JAMESON, Fredric. A cultura do dinheiro. Petrópolis: Vozes, 2001. p. 36.)
} 
pessoas presas à Matriz têm sua consciência separada de seu corpo, o qual dorme inerte em um casulo repleto de líquido amniótico. O que vemos são milhares de baterias humanas. Corpo e mente estão alienados do controle humano. O corpo repousa sob um manto gosmento, enquanto a mente está presa na ilusão criada pela Matriz. Nessa condição, o homem está totalmente privado do controle de suas ações. Nesse estado, ele deixa de existir enquanto ser autônomo e passa a ter uma existência meramente orgânica. As metáforas vegetais usadas no filme corroboram essa visão. Nelas, os humanos são "cultivados" em "campos", como vegetais.

Até serem resgatados, os humanos presos à Matriz têm sua mente mergulhada numa ilusão. O mundo em que eles circulam é uma construção, uma ficção diretamente inserida em seu cérebro. Alguns poucos superam esse estado de passividade involuntária e evoluem para um estágio de "ansiedade existênciap6". "O Recorde Mundial", uma das narrativas do DVD "Animatrix" (conjunto de nove animações que trazem histórias sobre a Matriz ou que a tem como cenário) começa com uma explicação do narrador:

Só as pessoas mais excepcionais tomam consciência da Matriz. Quem descobre que ela existe deve possuir um raro grau de intuição, sensibilidade e uma natureza questionadora.

\footnotetext{
96 "Na maior parte do tempo, nós (e esse "nós" inclui os filósofos que trabalham em tempo integral com as questões "definitivas" e insolúveis do ser) vivemos no estado do que Anthony Giddens chamou de segurança ontológica - "um sentido de fidedignidade das pessoas e das coisas", auxiliado e favorecido pela "previsibilidade das (aparentemente) menores rotinas da vida diária". O oposto da segurança ontológica é a ansiedade existencial." (BAUMAN, Zygmunt. O Mal-Estar da Pós-Modernidade. Rio de Janeiro: Jorge Zahar, p. 209).
} 
Todos, antes de serem libertados, devem optar entre a pílula azul, que garante um retorno sem traumas à normalidade, e a vermelha, ingresso para a aventura da liberdade. Sendo assim, adesão à resistência é voluntária. Aqui, estabelece-se uma "ética da liberdade", segundo a qual a liberdade só pode ser dada àqueles que a necessitam e a desejam. Evita-se, com isso, o paradoxo da liberdade imposta. Um fator complica essa equação: as pessoas presas à Matriz sequer têm conhecimento da sua condição de escravos. Assim, essa "ética da liberdade" (a possibilidade de escolher entre as pílulas azul e vermelha) é falsa, uma vez que a possibilidade da escolha só é dada àqueles já inclinados a optar pela ruptura com a Matriz.

É o que acontece com Neo. Em nenhum momento ele hesita em aceitar a pílula vermelha. Do ponto de vista do espectador, não existe a escolha acima mencionada, uma vez que a opção pela pílula vermelha é condição para a seqüência do enredo. Se Neo não houvesse optado por ela, não haveria a história que conhecemos. A escolha também não existe para Morfeu. Como ele acredita na profecia, sendo Neo o escolhido (como Morfeu acredita ser), não há chances da escolha pela pílula azul, já que isso implicaria no não cumprimento do destino profetizado.

Em Matrix, a festa de liberdade é para poucos convidados. Todos os que não possuem "uma natureza questionadora", são de pouco ou nenhum interesse para os resistentes e, quando necessário, são mortos como meros personagens de videogame.

Em diálogo com Neo, Morfeu explica que "anyone we haven't unplugged is potentially an agent. Inside the Matrix, they are everyone and they are no 
one". Portanto, como esclarece Morfeu, "If you are not one of us, you are one of them".

A questão da liberdade, em Matrix, é colocada como um problema de ordem individual. Para ingressar nas fileiras da resistência, é preciso antes obter um certo grau de consciência sobre a condição dos humanos presos à Matriz. Quem não alcançar alguma clareza cognitiva em relação à sua "realidade" dentro da Matriz é potencialmente um obstáculo para a elite dos cognitivamente iluminados, como nos explica, novamente, Morfeu:

The Matrix is a system, Neo. That system is our enemy. But when you're inside, you look around. What do you see? Business people, teachers, lawyers, carpenters. The very minds of the people we are trying to save. But until we do, these people are still a part of that system, and that makes them our enemy. You have to understand, most of these people are not ready to be unplugged. And many of them are so inert, so hopelessly dependant on the system, that they will fight to protect it.

O único indício de coletividade que vemos no processo de libertação da Matriz está na dependência que todos os libertados têm em relação à ajuda dos resistentes. Nem mesmo Neo, o Escolhido, pode prescindir dessa ajuda. Mesmo assim, a participação do grupo de resistentes na libertação daqueles presos à Matriz aparece como mero coadjuvante para o grande esforço individual de auto-libertação. Em diálogo com um dos libertados da Matriz, Neo 
atribui o sucesso no processo de libertação a um esforço pessoal do individuo resgatado:

Garoto: the more I think about it, the more I think it's meant to be. You know, it's fate. I mean, you're the reason I'm here, Neo.

Neo: I told you, Kid, you found me, I didn't find you.

Garoto: I know, but you got me out! You saved me!

Neo: You saved yourself.

Essa ênfase na individualidade da ação perpassa toda a narrativa. A conhecida inscrição que ficava na entrada do templo de Apolo em Delfos, "conheça-te a ti mesmo", está também presente na cozinha/consultório da Oráculo de Matrix. Em pelo menos duas ocasiões, a Oráculo chama a atenção de Neo para a frase, com o intuito de reafirmar o livre-arbítrio e a questão ética da escolha como paradigma de ação. Desprovidos de quaisquer balizas éticas, os personagens de Matrix contam apenas consigo mesmos para decidirem sobre os caminhos que tomarão. O "conheça-te a ti mesmo" de Matrix encerra mais lições sobre a contemporaneidade do que a pretensa sabedoria de sua alegada mensagem universal pode sugerir. $O$ mergulho na individualidade sugerido em Matrix é sintomático do estado de desorientação ético-moral da contemporaneidade:

Já que ser um indivíduo comumente se traduz por 'ser diferente dos outros' e é do 'eu' que se espera destaque, a tarefa 
parece intrinsecamente auto-referencial. Parece que quase não temos escolha senão buscar um indício de como se aprofundar cada vez mais no 'interior' de nós mesmos, aparentemente o nicho mais privado e protegido num mundo de experiências parecido com um bazar lotado e barulhento. Eu procuro pelo meu 'verdadeiro eu' que suponho estar escondido em algum lugar da obscuridade do meu eu prístino, não-afetado (não-poluído, nãosuprimido, não-deformado) pelas pressões externas. Eu traduzo o ideal de 'individualidade' como autenticidade, como 'ser fiel a mim mesmo', ser o 'verdadeiro eu'. Tento realizar uma espécie de 'insight fenomenológico' ao estilo de Husserl, embora simples e mal-acabado, em minha 'subjetividade' genuinamente 'transcendental', verdadeira e inalterada - por meio do esforço angustiante da 'redução fenomenológica', ou seja, 'deixando para trás', suspendendo, cortando ou eliminando qualquer corpo estranho que se possa considerar importado do mundo exterior ${ }^{97}$.

O conceito de homo eligens ("o 'homem que escolhe' (embora não o 'homem que escolheu'!): um ego permanentemente impermanente, completamente incompleto, definitivamente indefinido - e autenticamente

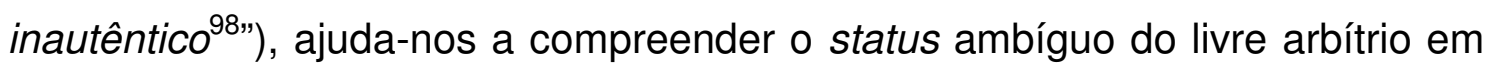
Matrix.

No primeiro encontro de Neo com Morfeu, temos o seguinte diálogo:

\footnotetext{
${ }^{97}$ BAUMAN, Zygmunt. Vida Líquida. Rio de Janeiro: Jorge Zahar, 2007. p. 27.

${ }^{98}$ Ibid., p. 48.
} 
Morfeu: Do you believe in fate, Neo?

Neo: No.

Morfeu: Why?

Neo: Because I don't like the idea that I'm not in control of my own life.

Essa tônica na escolha se mantém até o final da trilogia, mesmo diante da existência da profecia. O status ambíguo do livre arbítrio em Matrix reside no fato de que os personagens que acreditam piamente na liberdade de escolha não vêem o menor conflito entre essa liberdade e a profecia a que todos estão submetidos. Assim, para esses personagens, a ilusão da livre escolha é sustentada mesmo dentro de um sistema totalmente fechado a qualquer margem de autonomia individual.

A constituição psicológica desses personagens (essa predisposição de sustentar uma ilusão de livre arbítrio) é coerente com o comportamento social do homo eligens:

O homo eligens e o mercado de commodities coexistem em perfeita simbiose. Ambos não viveriam para ver o dia seguinte se não fossem apoiados e nutridos pela companhia um do outro. $O$ mercado não sobreviveria caso os consumidores se apegassem às $\operatorname{coisas}^{99}$.

${ }^{99}$ Idem. 
A ênfase na individualidade representa um enfraquecimento dos projetos coletivos. A metáfora de Marx, relatada por Bauman no trecho a seguir, fala eloqüentemente da questão da individualidade no contexto atual:

Como tarefa, a individualidade é o produto final de uma transformação societária disfarçada de descoberta pessoal. No estágio inicial dessa transformação, o jovem Karl Marx, ainda no colégio, observou numa redação que mosquitos buscavam a luz da lâmpada doméstica após o pôr-do-sol. Com efeito, o fascínio das lâmpadas domésticas aumentava à medida que o mundo lá fora escurecia. O emergir da individualidade assinalou um progressivo enfraquecimento, a desintegração ou destruição da densa rede de vínculos sociais que amarrava com força a totalidade das atividades da vida. Assinalou também que a comunidade estava perdendo o poder - elou interesse - de regular normativamente a vida de seus membros. Mais precisamente, assinalou que, não mais sendo an sich (nos termos de Hegel) nem zuhanden (como diria Heidegger), a comunidade havia perdido a antiga capacidade de fazer rotineiramente o trabalho de regulação, de modo trivial e sem embaraço. Tendo perdido essa habilidade, veio à tona, como um problema, a questão de moldar e coordenar as ações humanas, considerando-a um tema de ponderação e preocupação, e um objeto de escolha, decisão e esforço direcionado. 
Progressivamente, os padrões da rotina diária foram deixando de ser vistos como incontestáveis e auto-evidentes. O mundo da vida cotidiana estava perdendo sua auto-evidência $e$ a "transparência" de que havia usufruído no passado, quando os itinerários existenciais eram livres de encruzilhadas e de obstáculos a serem evitados, negociados ou forçados a abrir caminho $^{100}$.

A Oráculo é a porta-voz da individualidade, lembrando e relembrando os personagens de que eles, somente eles, são responsáveis por suas ações. A contradição não poderia ser maior, uma vez que a Oráculo, pregadora do evangelho da individualidade, é a mesma que porta os segredos da profecia.

$\mathrm{Na}$ ausência de paradigmas de ação claros, a profecia cumpre o papel de "metanarrativa", de guia para a ação revolucionária dos resistentes. 0 equilíbrio precário que podemos observar no tecido narrativo de Matrix entre a autonomia e a sua ausência (nos termos do filme, entre escolha e a profecia) figura um suspiro de individualidade num mundo cada vez mais "administrado", em que os espaços de exercício da autonomia são cada dia mais escassos.

A presença do Escolhido, aquele que guiará o seu povo à liberdade, reforça a contradição entre escolha individual e predeterminação dos acontecimentos. A existência de uma profecia, que é constantemente

${ }^{100}$ Ibid., p. 31. 
contestada pela escolha (os personagens acreditam que escolhem livremente seus caminhos) e confirmada pela sua realização, reafirma essa contradição. Tem-se, na verdade, uma falsa escolha: escolhe-se aquilo que já estava previsto para acontecer pela profecia.

Essa contradição da escolha pelo já determinado (escolha dentro da profecia) é o negativo irônico dos dilemas do pensamento político em tempos de "fim da história". A ilusão de escolha que os personagens de Matrix sustentam indica uma falha de "mapeamento cognitivo". Num horizonte sem alternativas políticas claras, tomado pela idéia de inevitabilidade (essa palavra é insistentemente repetida pelo personagem Smith a Neo, que reage sempre), as escolhas que temos são poucas, quando não falsas e redundantes. Os simulacros de escolha que aparecem em Matrix dão forma à experiência de um mundo em que

a aura de destino inescapável que parece envolver a irreversibilidade putativa da globalização nos força a confrontar nossa própria incapacidade de imaginar uma alternativa, ou de perceber como uma "desconexão" da economia mundial poderia vir a ser um projeto político e econômico possível ${ }^{101}$.

Despertos da ilusão da Matriz, os personagens vivem uma segunda ilusão, essa muito mais perversa do que a primeira, porque o seu caráter de irrealidade é disfarçado por uma suposta autoconsciência da liberdade.

${ }^{101}$ JAMESON, op. cit., p. 27. 
Essa inconsistência da autonomia, figurada no filme pelo paradoxo da falsa escolha (escolha x profecia), é ainda mais acentuada ao final de "Matrix Reloaded", quando vemos Neo usar seus poderes no mundo real. Nesse ponto, não temos mais certeza sequer do caráter real do mundo fora da Matriz. O filme termina com a perturbadora indicação de que não há mundo real, de que o "deserto do real" e a luta contra as máquinas é mais uma simulação gerada pela Matriz, um simulacro de revolução autorizado como medida profilática. Zizek descreve o problema:

By the end of The Matrix Reloaded, everything is cast in doubt: The question is not only whether any revolutions against the Matrix can accomplish what they claim or whether they have to end in an orgy of destruction, but whether they are not taken into account, planned even, by the Matrix itself. Are even those who are liberated from the Matrix free to make a choice at all? Is the solution to nonetheless risk the outright rebellion, or to resign oneself to play the local games of "resistance" while remaining within the Matrix, or even engage in collaboration with the "good" forces in the Matrix? This is where The Matrix Reloaded ends: in a failure of "cognitive mapping" that perfectly mirrors the sad predicament of today's left and its struggle against the System ${ }^{102}$.

102 ZIZEK, Slavoj. Ideology Reloaded In In These Times, 6 de junho de 2003. Disponível em http://www.lacan.com/zizekloaded.htm 
Essa indefinição se torna ainda mais aguda quando, no próximo e último filme da série, nenhuma explicação definitiva é dada para o fenômeno da extensão dos poderes de Neo para fora da Matriz ${ }^{103}$. Na única ocasião em que esse assunto é levantado, pouco do que é dito colabora para que essa indefinição seja resolvida:

Neo: Tell me how I separated my mind from my body without jacking in. Tell me how I stopped four sentinels by thinking it. Tell me just what the hell is happening to me. Oráculo: The power of the One extends beyond this world. It reaches from here all the way back to where it came from Neo:Where?

Oráculo: The Source. That's what you felt when you touched those Sentinels. But you weren't ready for it. You should be dead, but apparently you weren't ready for that, either.

Como num interminável quebra-cabeças, sempre há uma peça faltando em Matrix. A resposta dada pela Oráculo somente adia uma explicação definitiva, substituindo-a por um novo problema. O filme termina sem que essa questão seja retomada e sem explicar por que Neo mantém seus poderes fora da Matriz. Zizek indica as possibilidades deixadas ao final de "Matrix Reloaded":

\footnotetext{
${ }^{103}$ Nas cenas finais do filme anterior, "Matrix Reloaded" Neo consegue parar, usando seus poderes, as máquinas que o perseguem. $\mathrm{O}$ inusitado é que isso ocorre fora da Matriz, no mundo real.
} 
When, at the end of Matrix Reloaded, a miracle occurs in reality itself, there are only two ways out left open: either postmodern Gnosticism or Christianity. That is to say, either we shall learn, in part III [Matrix Revolutions], that "real reality" itself is just another matrix-generated spectacle, there being no last "real" reality, or we enter the domain of divine magic ${ }^{104}$.

Contrariando a previsão de Zizek, nenhuma dessas possíveis explicações se confirma em "Matrix Revolutions". A solução dada para o problema é a manutenção da ambigüidade. Nem mágica, nem gnosticismo pós-moderno, apenas indefinição. Nada mais expressivo da atual conjuntura político-social.

A trilogia termina sem dissipar a suspeita de que a resistência não passa de mais uma simulação. Sobre essa indefinição do enredo de Matrix, Baudrillard comenta:

Matrix é, desse ponto de vista, um objeto extravagante, simultaneamente cândido e perverso, em que não há aqui e lá. $O$ pseudo-Freud que fala ao final do filme [Matrix Reloaded] o diz bem: em determinado momento, foi necessário reprogramar a Matriz de modo a integrar as anomalias à equação. E vocês, os

${ }^{104}$ Idem. 
oponentes, fazem parte. Estamos, portanto, dentro de um circuito virtual total, onde não há exterior ${ }^{105}$.

Em Matrix, os impasses são respondidos com novos impasses até a suspensão da questão, que é ignorada e deixada em aberto. Essa é a epistemologia travada de Matrix. Os impasses colocados caminham numa espécie de progressão aporética. Podemos ver essa progressão na própria seqüência dos filmes, como Zizek observa:

If part one was dominated by the impetus to exit the Matrix, to liberate oneself from its hold, part two makes it clear that the battle has to be won within the Matrix, that one has to return to it. The filmmakers have thus dramatically raised the stakes of the Matrix series, confronting us with all the complications and confusions of the politics of liberation. And they have put themselves in a profoundly difficult spot: They now confront an almost impossible task. If the forthcoming part three, The Matrix Revolutions, is to succeed with anything like a happy ending, it will have to produce nothing less than the appropriate answer to the

\footnotetext{
${ }^{105}$ Baudrlillard decode Matrix. Le Nouvel Observateur, 19 jun. 2003. No original: Matrix est à cet égard un objet extravagant, à la fois candide et pervers, où il n'y a ni en deçà ni au-delà. Le pseudo-Freud qui parle à la fin du film le dit bien: à un moment, on a dû reprogrammer la Matrice pour intégrer les anomalies dans l'équation. Et vous, les opposants, vous en faites partie. On est donc, semble-t-il, dans un circuit virtuel total où il n'y a pas d'extérieur.
} 
dilemmas of revolutionary politics today, a blueprint for the political act the left is desperately looking for ${ }^{106}$.

A trégua proposta no final da trilogia não dá notícias de tempos melhores.

\section{"Ignorance is bliss": Cypher e a desilusão}

A "ética da liberdade", acima discutida, é contestada quando o personagem Cypher $^{107}$ decide reintegrar-se à Matriz. Esse personagem, que figura uma posição cética em relação à liberdade, é desenhado como um traidor da causa justa, como um egoísta disposto a liquidar seus companheiros para obter vantagens pessoais. Aqui, vemos exposta a fragilidade da "ética da liberdade". A inclusão de Cypher (o contestador da liberdade) no enredo do filme poderia servir de provocação para uma discussão interessante entre a

${ }^{106}$ ZIZEK, op. cit.

${ }^{107}$ Esse é parte do diálogo em que Cypher fecha o acordo para o seu retorno à Matriz: Agent Smith: So we have a deal, Mr. Reagan? / Cypher: You know, I know this steak doesn't exist. I know that when I put it in my mouth, the Matrix is telling my brain..that it is juicy..and delicious. After nine years, you know what I realize? Ignorance is bliss / Agent Smith: Then we have a deal? / Cypher: I don't want to remember nothing. Nothing. You understand? And I wanna be rich..you know, someone important. Like an actor / Agent Smith: Whatever you want...Mr. Reagan... / Cypher: Okay. I get my body back into a power plant, re-insert me into the Matrix, I'll get you what you want. 
escolha por uma existência autêntica e penosa ("deserto do Real") ou por uma prazerosa ilusão dentro da Matriz. Essa discussão sobre os atrativos do sistema e as agruras da oposição a ele não é desenvolvida na narrativa. Pelo contrário, a inclusão de Cypher somente confirma a idéia de que a escolha pela liberdade, não importa o sofrimento que isso possa ocasionar, é um imperativo ético. A escolha de Cypher pela simulação é demonizada e rejeitada como uma espécie de "suicídio ontológico". Retratado quase que como um vilão melodramático, Cypher é justa e adequadamente, dentro dos parâmetros éticos criados pelo filme, punido com a morte pela perturbação que sua escolha causa na lógica da dicotomia entre o real e o virtual. Assim, a cooptação pelo sistema (representada pela escolha de Cypher) é rebatida com a afirmação da ruptura como obrigação ética.

Essa ênfase na ética expõe uma dificuldade de se figurar uma alternativa que justifique a ruptura com o "sistema" como uma saída de uma realidade opressora para um autêntico "reino da liberdade". Na ausência dessa alternativa (que se justificaria por si só em comparação com o atual) apela-se para a transcendência fácil ou para outras abstrações tais como a "autenticidade" e a "humanidade". A ruptura com a Matriz é vista menos como uma "promessa de bonheur" e mais como um imperativo ético.

Cypher não apenas pretende deixar a vida cinzenta do mundo real, mas também almeja uma existência fabulosa, que só a Matriz pode lhe proporcionar. Ele quer ser rico e importante, viver um mundo de sonhos. Escolhe a profissão de ator. A ironia dessa escolha é obvia: Cypher, como ator, protagonizará fantasias dentro da sua própria ilusão. 
O conteúdo político do episódio Cypher fica ainda mais evidente quando atentamos para o seu sobrenome ${ }^{108}$ : Reagan. A referência ao presidente americano Ronald Reagan fica ainda mais explícita quando Cypher declara seu desejo de ser alguém rico e importante e escolhe a carreira de ator ${ }^{109}$.

A anemia revolucionária que o personagem Cypher (senhor Reagan) representa ganha contornos históricos mais precisos quando pensamos na conotação política que a referência a esse presidente americano carrega. Com - governo Reagan tem-se início uma virada à direita na política norteamericana e mundial. Perry Anderson sumariza a situação do mundo pósReagan:

Na década de 80, uma direita vitoriosa passou à ofensiva. No mundo anglo-saxônico, os regimes Reagan e Tchatcher, depois de anularem o movimento operário, fizeram recuar a regulamentação e a redistribuição. Espalhando-se da GrãBretanha para o resto da Europa, a privatização do setor público, os cortes nos gastos sociais e altos níveis de desemprego criaram um novo padrão de desenvolvimento neoliberal, por fim adotado tanto por partidos de esquerda quanto de direita. No final da década, a missão social-democrata de pós-guerra na Europa Ocidental - o bem-estar social baseado no pleno emprego e no

\footnotetext{
${ }^{108}$ Os personagens em Matrix possuem um nome "civil" para a sua vida na Matriz e um outro nome que usam para suas atividades subversivas como Hackers e para a vida fora da Matriz. Neo, por exemplo, chama-se Thomas Anderson dentro da Matriz. Trocar de nome, ou assumir definitivamente o nome de Hacker, é parte do ritual de abandono da Matriz.

109 Antes de ser presidente dos Estados Unidos, Ronald Reagan atuou em 53 produções Hollywoodianas.
} 
abastecimento geral - tinha sido abandonada pela Internacional Socialista. Na Europa Oriental e na União Soviética, o comunismo - incapaz de competir economicamente no exterior ou de se democratizar em casa - foi completamente destroçado. No Terceiro Mundo, Estados nascidos de movimentos de libertação nacional foram pegos por toda a parte na armadilha das novas formas de subordinação internacional, incapazes de escapar às pressões dos mercados financeiros mundiais e de suas instituições supervisoras ${ }^{110}$.

Os dilemas aqui apontados permanecem desafiando o pensamento crítico contemporâneo. O clima de derrotismo e irreversibilidade que vem se acentuando desde os anos 80 é o cenário histórico que ajuda a entender alguns dos impasses que saturam Matrix.

\section{Ambigüidades e zonas de indefinição}

A divisão entre o universo humano e o da máquina, esboçada no primeiro filme da trilogia, é posta em questão pelas falhas e contradições do

${ }^{110}$ ANDERSON, Perry. As origens da Pós-Modernidade. Rio de Janeiro: Jorge Zahar, 1999. pp. $107-8$. 
tecido narrativo, que vão aparecendo e se tornando mais agudas com o desenrolar da trama. Como observa Zizek,

The Matrix Reloaded proposes - or, rather, plays with - a series of ways to overcome the inconsistencies of its prequel. But in doing so, it gets entangled in new inconsistencies of its own. The film's end is open and undecided not only narratively, but also with regard to its underlying vision of the universe. The basic tone is that of additional complications and suspicions that render problematic the simple and clear ideology of liberation from the Matrix that underpins the first film ${ }^{111}$.

A separação entre os dois mundos logo se revelará falha. Vejamos alguns fatos que contrariam a definição da Matriz e do mundo real como duas realidades ontologicamente distintas.

A maior evidência da frágil separação entre os dois mundos aparece no episódio, acima discutido, em que Neo consegue usar seus poderes fora da Matriz.

Assim, a separação, inicialmente insinuada, entre o humano e o mundo da máquina vai sendo contestada por falhas e inconsistências do mundo ficcional apresentado em Matrix. Para Zizek,

The first sign of this failure is simply the contract with spectators broken. The ontological premise of The Matrix (part

${ }^{111}$ ZIZEK, op. cit. 
one) is a straightforward realistic one: there is the "real reality" and the virtual universe of the Matrix which can be entirely explained in the terms of what went on in reality. Matrix Revolutions breaks these rules: in it, the "magic" powers of Neo and Smith extend into "real reality" itself (Neo can stop bullets there also, etc.). Is this not like a detective novel in which, after a series of complex clues, the proposed solution would be that the murderer has magic capacities and was able to commit his crime violating laws of our reality? The reader would feel cheated - the same as in Matrix Revolutions, where the predominant tone is the one of faith, not knowledge $e^{112}$.

As contradições que envolvem a delimitação dos dois mundos também aparecem no conflito homem-máquina. Como vimos na primeira parte desse capítulo, o impulso inicial é pela definição de fronteiras entre o humano e o universo da máquina. Vimos como esse impulso se filia a uma longa tradição, a das manifestações do "anticapitalismo romântico". Agora, veremos como a separação rigorosa entre homem e máquina vai, ao longo da trilogia, sendo sutilmente minada por inconsistências do tecido ficcional.

Tentativas de se pensar a relação entre homem e técnica sempre correm o risco de desviar para dicotomias (cujos problemas estudamos acima) e/ou para um ingênuo ludismo. Ver a técnica como força autônoma causadora de problemas sociais é já reificá-la. Criticar a técnica como algo que tem uma evolução própria e alheia à vontade humana é eximir o homem da

\footnotetext{
${ }^{112}$ Idem.
} 
responsabilidade pelas formas sociais que a técnica pode assumir. Adorno identifica esse movimento de separação na crítica de Huxley à sociedade capitalista:

Huxley não admite que a desumanidade fantasmagórica do Brave New World é uma forma esquecida de relação humana, é trabalho social; ele não admite que o homem totalmente reificado é o homem que ofuscou a si mesmo. Em vez disso, Huxley atiça o confronto entre fenômenos superficiais não analisados, no estilo do 'conflito entre o homem e a máquina'. Seguindo a crença dos filisteus românticos, ele atribui à técnica uma culpa... que não reside nela mesma, mas é a conseqüência, como aliás se entrevê em certas passagens do romance, de seu entrelaçamento com as relações sociais de produção ${ }^{113}$.

Em Matrix, a tentativa de pensar a relação homem-máquina pela delimitação de limites entre eles acaba revelando uma série de ambigüidades. O amor, que inicialmente aparece como elemento de diferenciação entre o mundo humano e o mundo da máquina, aparece também associado aos nãohumanos. Em "Matrix Revolutions", ponto alto das ambigüidades, conhecemos Rama-Kandra, um "gerenciador de sistemas de energia para operações de reciclagem", como ele mesmo se apresenta. Esse autômato se singulariza por uma característica inusitada: ele ama sua mulher, Kamala (uma "altamente criativa programadora de softwares interativos") e sua filha Sati, pela qual está

${ }^{113}$ ADORNO, op. cit. p. 110. 
disposto a se sacrificar. Em diálogo com Neo, Rama explica a natureza do seu amor:

Neo: I just have never...

Rama-Kandra: ...heard a program speak of love?

Neo: It's a... human emotion.

Rama-Kandra: No, it is a word. What matters is the connection the word implies. I see that you are in love. Can you tell me what you would give to hold on to that connection?

Neo: Anything.

Rama-Kandra: Then perhaps the reason you're here is not so different from the reason I'm here.

A contradição não poderia ser mais evidente: o Amor, que é evocado em vários momentos como elemento de distinção do homem frente à máquina, aparece aqui explicado e desmistificado por um autômato. É como se a máquina reagisse à tentativa (feita por meio das antinomias já estudadas) de delimitação de um espaço estritamente humano e reivindicasse a ambigüidade.

Outras personagens também experimentam sentimentos humanos. A ciumenta e vingativa Perséfone, esposa do Merovíngio, vinga-se de uma traição do seu marido entregando o personagem Chaveiro para os resistentes. Antes disso, ela pede a Neo um beijo apaixonado e reclama de que seu marido não é mais o mesmo homem, e de que ela há muito não sabe o que é o amor: 
Perséfone: If you want the Keymaker, follow me. I'm so sick of his bullshit. On and on, pompous prick. A long time ago, when we first came here, it was so different. He was so different. He was like you. I'll give you what you want. But you have to give me something.

Neo: What?

Perséfone: $A$ kiss.

Perséfone: I want you to kiss me as if you were kissing her [Trinity].

Neo: Why?

Perséfone: You love her. She loves you. It's all over you both. A long time ago, I knew what that felt like. I want to remember it. I want to sample it. That's all, just a sample.

Outra ambigüidade de Matrix está no fato de que a "desconexão" com o mundo das máquinas não implica no abandono da tecnologia por uma forma de vida mais orgânica. Com o mundo real totalmente devastado, simplesmente não há natureza para abrigar um possível retorno. O contrário do mundo das máquinas, em Matrix, é um cenário desolador, uma cidade subterrânea que sobrevive graças à existência de máquinas. Além disso, a luta dos resistentes se dá totalmente na dependência das máquinas. Elas são necessárias para transitar pelos esgotos gigantescos do submundo; para entrar na Matriz, para combater as máquinas que tentam invadir a cidade de Sião. O paradoxo dessa dependência em relação ao objeto combatido é endereçada pelo personagem Conselheiro Hamann: 
Conselheiro Hamann: Almost no one comes down here, unless, of course, there's a problem. That's how it is with people - nobody cares how it works as long as it works. I like it down here. I like to be reminded this city survives because of these machines. These machines are keeping us alive, while other machines are coming to kill us. Interesting, isn't it? Power to give life, and the power to end it.

Neo: We have the same power.

Conselheiro Hamann: I suppose we do, but down here sometimes I think about all those people still plugged into the Matrix and when I look at these machines, (...) can't help thinking that in a way, we are plugged into them. Neo: But we control these machines, they don't control us. Conselheiro Hamann: Of course not, how could they? The idea's pure nonsense, but... it does make one wonder just... what is control?

Neo: If we wanted, we could shut these machines down. Conselheiro Hamann: Of course... that's it. You hit it! That's control, isn't it? If we wanted, we could smash them to bits. Although if we did, we'd have to consider what would happen to our lights, our heat, our air.

Neo: So we need machines and they need us. Is that your point, Councillor? 
Conselheiro Hamann: No, no point. Old men like me don't bother with making points. There's no point.

Como um Sócrates subterrâneo, o Conselheiro propõem um problema e, a cada resposta de seu interlocutor, coloca novos questionamentos. A atitude de Neo é quase intransigente, beira a rigidez dogmática. O diálogo termina com Neo pedindo para o Conselheiro dizer logo o que deseja falar. Assim, essa reflexão é suspensa e não mais retomada pelos personagens.

Esse paradoxo está presente na própria concretização do empreendimento cinematográfico Matrix. Os filmes da série abusam dos efeitos especiais sem que isso constitua o menor obstáculo ético para a amarga crítica da tecnologia que o filme parece querer sustentar. Assim, Matrix utiliza altas doses de tecnologia justamente para tecer uma crítica da onipresença da tecnologia no mundo contemporâneo. Essa contradição de Matrix é comentada por Baudrillard:

O que chama a atenção em Matrix é que não há sequer uma gota de ironia que permita ao espectador ver esse gigantesco efeito especial ao contrário. Nem ao menos uma seqüência que traga aquele "Punctum" do qual Barthes fala, aquela surpreendente astúcia que nos coloca diante de uma imagem verdadeira. De resto, é isso que torna o filme um sintoma instrutivo e o próprio fetiche das tecnologias da tela, onde não há mais distinção entre o real e o imaginário. Matrix é, desse ponto 
de vista, um objeto extravagante, simultaneamente cândido e perverso, em que não há aqui e lá114.

Matrix está repleto de momentos como esses. Antes de estudá-los, é preciso separar as citações filosóficas explícitas e as citações de problemas filosóficos dos momentos em que há um esforço de cognição, uma tentativa de "mapeamento cognitivo". Essas zonas de ambigüidade e indefinição que destacamos acima são exemplos desses momentos de cognição.

Dois personagens importantes da trama de Matrix são também pólos concentradores de ambigüidades e indefinição: o agente Smith e a Oráculo.

A Oráculo desempenha um papel fundamental no enredo de Matrix: ela é a guardiã da profecia, que é o motor da narrativa. Aqui reside o problema e a ambigüidade desse personagem. Como entender a atuação da Oráculo na resistência? Não sendo humana, que explicação haveria para o interesse desse personagem na luta contra as máquinas? Na única ocasião em que essa

\footnotetext{
${ }^{114}$ Baudrlillard decode Matrix. Le Nouvel Observateur, 19 jun. 2003. No original: Ce qui est très frappant dans Matrix 2, c'est qu'il n'y a pas une lueur d'ironie qui permette au spectateur de prendre ce gigantesque effet spécial à revers. Pas une séquence qui aurait ce 'punctum' dont parle Barthes, ce truc saisissant qui vous mette face à une véritable image. C'est du reste ce qui fait du film un symptôme instructif, et le fétiche même de cet univers des technologies de l'écran, où il n'y a plus de distinction entre le réel et l'imaginaire. Matrix est à cet égard un objet extravagant, à la fois candide et pervers, où il n'y a ni en deçà ni au-delà.
} 
dúvida é colocada, a resposta, como em outras passagens do filme, gera mais ambigüidades do que definição:

Neo: You're not human, are you?

Oráculo: Well it's tough to get any more obvious than that. Neo: If I had to guess, I'd say you're a program from the machine world.

Oráculo: So far, so good.

Neo: But if that's true, that can mean you are a part of this system, another kind of control.

Oráculo: Keep going.

Neo: I suppose the most obvious question is, how can I trust you?

Oráculo: Bingo! It is a pickle, no doubt about it. The bad news is there's no way if you can really know whether I'm here to help you or not. So it's really up to you. You just have to make up your own damn mind to either accept what I'm going to tell you, or reject it. Candy?

Neo: Why are you here?

Oráculo: Same reason. I love candy.

Neo: But why help us?

Oráculo: We're all here to do what we're all here to do. I'm interested in one thing, Neo, the future. And believe me, I know - the only way to get there is together. 
Neo: Are there other programs like you?

Oráculo: Oh, well, not like me. But... Look, see those birds? At some point a program was written to govern them. A program was written to watch over the trees, and the wind, the sunrise, and sunset. There are programs running all over the place. The ones doing their job, doing what they were meant to do, are invisible. You'd never even know they were here. But the other ones, well, we hear about them all the time.

A continuação desse diálogo não é nada esclarecedora. A dúvida sobre a possibilidade de confiança da resistência na Oráculo é transferida para Neo. Ele é quem tem que decidir se deve ou não aceitar o que lhe é dito. A resposta imprecisa da Oráculo reafirma a presença ambígua desse personagem na trama de Matrix. É interessante observar como o filme vai gerando ambigüidades e produzindo respostas cada vez mais ambíguas para elas. A epistemologia travada de Matrix é sintoma da dificuldade do pensamento em lidar com o complexo de informações e problemas que marcam a experiência contemporânea. Procurar caminhos que auxiliem o pensamento a subsumir esse labirinto de discursos, vozes, informação... é, hoje, uma tarefa urgente.

O agente Smith é outro "personagem em busca de uma definição". No primeiro filme, ele é um agente a serviço da Matriz. Ao final da trilogia, ele domina a Matriz e torna-se inimigo tanto dos humanos quanto das máquinas. Ironicamente, o agente Smith, que no primeiro filme da trilogia demonstrava 
repúdio (com direito até a discurso e teoria ${ }^{115}$ ) aos humanos, acaba virando, ao final da série, o inimigo em comum que permite a aliança entre homens e máquinas e a negociação de uma trégua.

O status indefinido de Smith se dá pela sua "abertura simbólica". Desde o primeiro filme da série, ele demonstra certa independência em relação à Matriz $^{116}$. Mesmo assim, e sem motivo aparente, ele continua perseguindo Neo e outros resistentes. Em "Matrix Reloaded", Smith começa a se reproduzir e a dominar a Matriz, também sem nenhuma explicação para tal sede de poder. No último filme da série, ele chega ao mundo real, quebrando assim a barreira entre os dois mundos. Como o tópos da máquina, que estudamos no começo desse capítulo, o personagem Smith, pela sua indefinição, pode comportar diversas possibilidades de leitura simbólica. Ele pode ser lido como o excesso gerado pelo próprio sistema, como o Kurtz de "Apocalypse Now"117; pode ser

\footnotetext{
${ }^{115}$ Agent Smith : I'd like to share a...revelation I had, during my time here. It came to me when I tried to...classify your species. I realized that you're not actually mammals. Every mammal on this planet instinctively develops a natural equilibrium with the surrounding environment but...you humans do not. You move to an area... and you multiply...until every natural resource is consumed. The only way you can survive is to. spread to another area. There is another organism on this planet that follows the same pattern. Do you know what it is? A virus. Humans beings are a disease, a cancer of this planet... and we... are the cure.
}

${ }^{116}$ A perseguição que Smith promove a Neo e aos resistentes é posta mais como um projeto pessoal do que como o cumprimento de uma obrigação Ele se singulariza entre os outros agentes pela sua tendência a agir por conta própria. Durante o interrogatório de Morfeu, ele chega a se "desligar" do sistema, tirando o fone de ouvido, prenunciando o que ocorreria mais tarde.

117 “O horizonte último de Apocalypse Now é essa idéia de como o Poder gera seus próprios excessos" (ZIZEK, Slavoj. Bem-vindo ao Deserto do Real!. São Paulo: Boitempo, 2003. p. 42) 
lido, também, como o apetite autofágico do sistema que, como no símbolo do ouroboros $^{118}$, devora a si mesmo até a auto-aniquilação; pode ser lido, no limite, como a encarnação de todo tipo de mal. Muitos livros que se apropriam da figura da Matriz para fins alegóricos diversos utilizam o personagem Smith como símbolo do pecado, do mal, do desejo de poder, do próprio Poder, da má consciência e outros males. Assim, esse personagem figura no filme como um significante polivalente, sem sentido definido. Como no caso da Oráculo, essa indefinição é sintomática.

\section{A máquina como totalidade}

Mapeadas as zonas de indefinição, chegamos a uma encruzilhada epistemológica na análise de Matrix.

Partimos do pressuposto de que as indefinições não são apenas "erros" de diagnóstico do filme, mas sim figurações de dilemas do pensamento contemporâneo.

Até aqui, abordamos a figura da máquina de diferentes perspectivas. Vimos essa figura como elemento retórico (o tópos da máquina). A partir desse estudo, verificamos como esse tópos (a máquina como "alegoria do socialmente negativo") pode servir de base para a construção de um protesto

\footnotetext{
${ }^{118}$ A cobra que devora o próprio rabo.
} 
contra o mundo capitalista. Inserimos o tópos da máquina no contexto mais amplo do "anticapitalismo romântico".

Feito isso, verificamos como o protesto anticapitalista pode se organizar em dicotomias, cujos pólos opõem o que o inconsciente coletivo de uma época concebe como males da sociedade ao que é imaginado como o oposto utópico dessa sociedade.

Expostas essas dicotomias, verificamos que, enquanto moldura do pensamento, essas oposições rígidas podem, ao tentar dar forma às tensões sociais vigentes, incorrer numa simplificação que pode revelar a incapacidade da imaginação histórica de subsumir os dilemas de sua época.

Se, por um lado, Matrix nos fornece uma imagem da reificação total, por outro, reforça o processo de reificação ao recorrer à dicotomias que, como falamos acima, corroboram esse mesmo processo. Essa contradição, uma dentre as várias que os filmes aqui estudados apresentam, oferece um relato significativo dos dilemas que 0 pensamento sobre os problemas contemporâneos tem que enfrentar. O mais significativo em Matrix não é a exposição desses dilemas (eles podem ser observados em muitos outros objetos de cultura), mas a tentativa de produzir uma síntese dos problemas atuais, de buscar um equilíbrio entre todos esses problemas; no limite, de buscar um "efeito de fechamento" ("closure-effect ${ }^{119 ")}$.

Estudamos alguns momentos da trilogia em que podemos observar uma suspensão do pensamento. Momentos em que a explicação e a certeza

\footnotetext{
${ }^{119}$ Cf. JAMESON, Fredric. The geopolitical aesthetic: cinema and space in the world system. Bloomington; London: Indiana University Press: BFI Pub., 1995.
} 
cessam e o raciocínio desaparece num vácuo de indefinição. Definimos esses momentos como exemplos da epistemologia travada de Matrix.

Tentamos, nessa trajetória, cercar conceitualmente a figura da máquina e buscar, a partir do estudo dessa figura e dos elementos ficcionais a ela associados, um leitmotiv analítico que pudesse oferecer uma saída para o buraco negro das indefinições.

Estabelecidos os pontos de indefinição, chegamos a um momento crucial dessa análise. Poderíamos encerrar o capítulo, satisfeitos com o apontamento de alguns dilemas chaves do mundo contemporâneo. Seria uma saída segura para não incorrermos no risco de cair na mesma indefinição que apontamos no filme.

Em vez disso, proporemos uma leitura que busque integrar todos esses dilemas num todo maior. Recorreremos, para isso, à leitura que Louis Althusser faz do conceito de Darstellung ${ }^{120}$, de Marx, e da relação desse conceito com a idéia de máquina como categoria epistemológica.

O capital resiste a qualquer tentativa de representá-lo como uma totalidade. Essa resistência à figuração é intrínseca ao regime de produção capitalista $^{121}$. Para Richard Dienst,

\footnotetext{
120 "In order to see all of capital's effects together as a chain of value, precisely as an economy, historical science must discover capital's mechanism for the production and distribution - that is, the transformation and transmission - of value. A few pages earlier, Althusser cites Marx's basic conceptual name for that mechanism Darstellung, representation, the "key epistemological concept of the whole Marxist theory of value, the concept whose object is precisely to designate the mode of presence of the structure in its effects, and therefore to designate structural causality itself'. (DIENST, op. cit., p. 42)

${ }^{121}$ Ibid., p.44.
} 
capitalism's fundamental mechanism, the determining force of the economic instance, can only be grasped as a certain kind of representation called Darstellung (which has yet to be defined) ${ }^{122}$.

O conceito de Darstellung faz, no nível da representação, com que "The exotic folds into the esotic - 'part' becomes 'whole' and vice versa - and the structure is designated completely in its effects ${ }^{123}$."

Segundo Dienst, o conceito de Darstellung permite-nos a fusão da representação e da idéia de máquina em um único conceito-metáfora ${ }^{124}$. Para Dienst, "'machinery' can be both the figure and the concrete mode of existence of Darstellung ${ }^{125 ",}$.

Althusser examina a metáfora do "mecanismo" em "O Capitaf", de Marx, e conclui:

Each time Marx presents the capitalist system as a mechanism, a machinery, a machine, a construction (montage) or as the complexity of a "social metabolism" .. . the ordinary distinctions between outside and inside disappear, along with the "intimate" links within the phenomena as opposed to their visible disorder: we find a different image, a new quasi-concept, definitely freed from the empiricist antimonies of phenomenal subjectivity

\footnotetext{
${ }^{122}$ Ibid., p. 42.

${ }^{123}$ Ibid., p. 43.

${ }^{124}$ Idem.

${ }^{125}$ Idem.
} 
and essential interiority; we find an objective system governed in its most concrete determinations by the laws of its construction (montage) and machinery, by the specifications of its concept. Now we can recall that highly symptomatic term "Darstellung" compare it with this "machinery" and take it literally, as the very existence of this machinery in its effects ${ }^{126}$.

Enquanto metáfora do funcionamento e da circulação do capital, a figura da máquina (mecanismo, maquinaria) apresenta uma vantagem epistemológica em relação a outras figuras:

Whereas all the other metaphors were "images" of the structure in its effects, machinery alone (notice how "metabolism" drops out) is already an "almost perfect" concept, a "quasiconcept", a concept in effect. The image of machinery absorbs its conceptual determination (Darstellung) and "literalizes" it. For an instant, Althusser appears to have resolved the abstract and the concrete, knowledge and its objects. Machinery is not only figurally adequate to the object 'capitalist system' but is also sufficient to 'produce the concept' of the structural determination operated by that system. Machinery both represents the force of representation

${ }^{126}$ ALTHUSSER Apud DIENST, op. cit. p.42. 
in Althusser's epistemology and deploys the force of representation in the capitalist economy ${ }^{127}$.

Em Matrix, podemos observar essa conceituação da totalidade das relações sociais como uma maquinaria. A figura da Matriz é, precisamente, um mundo-máquina, onde tudo tem sua função exata. A Matriz funciona como um mecanismo, onde tudo tem uma função específica e só faz sentido se exercêla, como vemos nessas explicações da Oráculo:

Oráculo: Look, see those birds? At some point a program was written to govern them. A program was written to watch over the trees, and the wind, the sunrise, and sunset. There are programs running all over the place. The ones doing their job, doing what they were meant to do, are invisible. You'd never even know they were here. But the other ones, well, we hear about them all the time.

Neo: I've never heard of them.

Oráculo: Of course you have. Every time you've heard someone say they saw a ghost, or an angel. Every story you've ever heard about vampires, werewolves, or aliens is the system assimilating some program that's doing something they're not supposed to be doing.

Neo: Programs hacking programs. Why?

Oráculo: They have their reasons, but usually a program

${ }^{127}$ DIENST, op. cit. p. 43. 
chooses exile when it faces deletion.

Neo: And why would a program be deleted?

Oráculo: Maybe it breaks down. Maybe a better program is created to replace it - happens all the time, and when it does, a program can either choose to hide here, or return to The Source.

Essa idéia de que tudo tem o seu lugar exato e pré-determinado é mimetizada pela própria estrutura narrativa. Como num jogo de videogame, a narrativa em Matrix segue uma série de etapas, em que, entre lutas e orgias de efeitos especiais, os personagens vão progredindo em direção a um objetivo pré-estabelecido.

Julian Stallabrass analisou a estrutura das narrativas em jogos de videogame e concluiu que, nesses jogos, o jogador experimenta a sensação de navegar por um universo rigidamente fechado, cujas regras são conhecidas e os limites visíveis. Nas palavras de Stallabrass: "The player of a computer game has the feeling of inhabiting a discrete world where unchangeable truths may be learned ${ }^{128,}$.

As narrativas de videogames geralmente empreendem um esforço alegórico para a criação de um "efeito de fechamento". Nesses mundos criados, o jogador caminha em chão firme, sabe o que fazer para atingir o seu objetivo. No universo do game, o jogador é solicitado a desempenhar o seu papel, a atingir a sua meta, sem que isso requeira qualquer pano de fundo

\footnotetext{
${ }^{128}$ STALLABRASS, Julian. Gargantua: manufactured mass culture. London; New York: Verso, 1996, p. 96.
} 
moral que dê significado às ações do jogador. Para Stallabrass, "Within limits, then, the plots of theses games show a degree of amoral lassitude ${ }^{129,}$. Para 0 jogador, as pessoas mortas, as cidades bombardeadas, as casas incendiadas etc... são ações moralmente neutras, meros obstáculos superados na conquista de um objetivo igualmente sem significação moral. O jogador se torna, assim, um operador de si mesmo, uma engrenagem voluntária e inconsciente que desempenha uma função, um sistema de significação indefinida. Stallabrass destaca esse processo de mecanização ao qual o jogador se submete:

Computer games force a mechanization of the body on their players in which their moviments and the image of their alter-ego provide a physical and a simulated image of the self under capital, subject to fragmentation, reification and the play of allegory. Games demand that their players hone their skills to make the body a machine, forging from the uncoordinated and ignorant body of the acolyte an embodiment of the spirit of the game ${ }^{130}$.

Em vários momentos, o enredo de Matrix segue o modelo de uma narrativa de videogame. Nesses momentos, personagens e ações aparecem desconectados do todo do enredo. Sua presença se esgota em si mesma. Isso acontece, por exemplo, na passagem do personagem Chaveiro pela trama. Nem os protagonistas da história sabem dar uma significação mais ampla para

\footnotetext{
${ }^{129}$ Ibid., 95.

${ }^{130}$ Ibid., 89.
} 
a existência desse novo personagem na trama, como esse diálogo no restaurante do Merovíngio revela:

Morfeu: You know why we are here.

Merovíngio: Hmph... I am a trafficker of information, I know everything I can. The question is, do you know why you are here?

Morfeu: We are looking for the Keymaker.

Merovíngio: Oh yes, it is true. The Keymaker, of course. But this is not a reason, this is not a 'why'. The Keymaker himself, his very nature, is means, it is not an end, and so, to look for him is to be looking for a means to do... what? Neo: You know the answer to that question. Merovíngio: But do you? You think you do but you do not. You are here because you were sent here, you were told to come here and you obeyed ${ }^{131}$.

Ao contrário do que acontece num Bildungsroman, o herói em Matrix não está exposto à insegurança e a imprevisibilidade de um processo de aprendizado e amadurecimento. Em vez disso, Neo geralmente sabe o que deve fazer, uma vez que ele é orientado pela Oráculo e conta com a segurança de uma profecia para organizar o seu destino.

A presença da profecia reforça o aspecto de mecanismo que observamos em Matrix. Como futuro já realizado, a profecia não deixa espaço

${ }^{131}$ Esse diálogo acontece em "Matrix Reloaded" 
para nenhuma agência. Na profecia de Matrix, tudo segue o seu curso conforme previsto, tornando o filme um mero desenrolar desse futuro fechado.

Há, em Matrix, uma ênfase no "propósito" (purpose, no original). Em diversos momentos, vemos personagens explicando a sua participação no enredo-game de Matrix a partir da idéia de "propósito". Podemos ver um exemplo disso na fala do personagem Chaveiro:

Niobe: How do you know all this?

Keymaker: I know because I must know. It's my purpose. It's the reason I'm here. Same reason we're all here.

No mundo totalmente "administrado" de Matrix, é o "propósito" que concede algum sentido, ou melhor, alguma função para a existência das coisas. Vemos isso na fala da Oráculo, quando ela relata a situação dos programas que não são mais úteis para a Matriz. Vemos essa ênfase no "propósito" exposta de maneira bem mais enfática nas seguintes linhas:

Smith: I killed you, Mister Anderson, I watched you die... With a certain satisfaction, I might add, and then something happened. Something that I knew was impossible, but it happened anyway. You destroyed me, Mister Anderson. Afterward, I knew the rules, I understood what I was supposed to do but I didn't. I couldn't. I was compelled to stay, compelled to disobey. And now here I stand because of you, Mister Anderson, because of you I'm no longer an 
agent of the system, because of you I've changed - I'm

unplugged - a new man, so to speak, like you, apparently free.

Neo: Congratulations.

Smith: Thank you. But as you well know, appearances can be deceiving, which brings me back to the reason why we're here. We're not here because we're free, we're here because we're not free. There's no escaping reason, no denying purpose - because as we both know, without purpose, we would not exist.

Smith 2: It is purpose that created us,

Smith 3: Purpose that connects us,

Smith 4: Purpose that pulls us,

Smith 5: That guides us,

Smith 6: That drives us,

Smith 7: It is purpose that defines,

Smith 8: Purpose that binds us.

Smith: We're here because of you, Mister Anderson, we're here to take from you what you tried to take from us. Purpose.

No universo totalmente racionalizado de Matrix, não há espaço para nada de gratuito e espontâneo (aqui, podemos entender melhor a ênfase dada ao amor e aos impulsos como reações a esse mundo). Tudo deve ter um propósito e ocupar um espaço determinado no mecanismo que rege o 
funcionamento desse sistema. Em Matrix, até a revolução (luta pela ruptura com o existente) segue um curso determinado e conhecido do sistema, no caso, a profecia. O ceticismo da revolução em Matrix nunca é explicitado verbalmente. Para os personagens, é como se a revolução acontecesse de fato e fosse conseqüência da escolha deles pela liberdade e pela oposição ao sistema. Para nós, espectadores, fica a suspeita de que a revolta é mais uma simulação, mais um mecanismo de controle a serviço da Matriz. Isso é insinuado pelo fato de Neo conseguir usar os seus poderes fora da Matriz. Esse fenômeno nunca é explicado. Portanto, a suspeita de que tudo o que presenciamos como espectadores não tenha passado de mais uma simulação da Matriz (da qual os personagens não têm ciência alguma) nunca é descartada.

A revelação de que a revolta e a profecia são fatos previstos e planejados pela Matriz acontece no diálogo de Neo com o Arquiteto:

Arquiteto: Your life is the sum of a remainder of an unbalanced equation inherent to the programming of the Matrix. You are the eventuality of an anomaly, which, despite my sincerest efforts, I have been unable to eliminate from what is otherwise a harmony of mathematical precision. While it remains a burden assiduously avoided, it is not unexpected, and thus not beyond a measure of control. Which has led you, inexorably... here.

Neo: You haven't answered my question.

Arquiteto: Quite right. Interesting. That was quicker than 
the others.

Neo: Others? How many others? What others? Answer my question!

Arquiteto: The Matrix is older than you know. I prefer counting from the emergence of one integral anomaly to the emergence of the next, in which case this is the 6th version. $(\ldots)$

Arquiteto: As you are undoubtedly gathering, the anomaly is systemic - creating fluctuations in even the most simplistic equations.

Neo: Choice. The problem is choice.

Arquiteto: The first Matrix I designed was quite naturally perfect, it was a work of art - flawless, sublime. A triumph equalled only by its monumental failure. The inevitability of its doom is apparent to me now as a consequence of the imperfection inherent in every human being. Thus, I redesigned it based on your history to more accurately reflect the varying grotesqueries of your nature. However, I was again frustrated by failure. I have since come to understand that the answer eluded me because it required a lesser mind, or perhaps a mind less bound by the parameters of perfection. Thus the answer was stumbled upon by another - an intuitive program, initially created to investigate certain aspects of the human psyche. If I am the 
father of the matrix, she would undoubtedly be its mother. Neo: The Oracle.

Arquiteto: Please. As I was saying, she stumbled upon a solution whereby nearly $99 \%$ of all test subjects accepted the program, as long as they were given a choice, even if they were only aware of the choice at a near unconscious level. While this answer functioned, it was obviously fundamentally flawed, thus creating the otherwise contradictory systemic anomaly, that if left unchecked might threaten the system itself. Ergo those that refused the program, while a minority, if unchecked, would constitute an escalating probablility of disaster.

Neo: This is about Zion.

Arquiteto: You are here because Zion is about to be destroyed - its every living inhabitant terminated, its entire existence eradicated.

The function of the One is now to return to the Source, allowing a temporary dissemination of the code you carry, reinserting the prime program. After which, you will be required to select from the Matrix 23 individuals - 16 female, 7 male - to rebuild Zion. Failure to comply with this process will result in a cataclysmic system crash, killing everyone connected to the Matrix, which, coupled with the 
extermination of Zion, will ultimately result in the extinction of the entire human race.

Esse diálogo ocorre depois do encontro de Neo com a Oráculo, em que esta, perguntada sobre sua relação com as máquinas, apenas responde que Neo deve decidir sozinho se pode ou não confiar nas informações dadas por ela. Após a revelação, feita pelo Arquiteto, de que a Oráculo é um programa designado para controlar os impulsos rebeldes da massa de baterias-humanas, o assunto não é retomado, deixando essa questão, como outras, em aberto.

A tolerância dos personagens com todos os fatos inexplicados da narrativa beira a inverossimilhança. Como não desconfiar, de forma mais sistemática, da atuação da Oráculo na revolução? Como aceitar como quase normal os poderes de Neo fora da Matriz? Como Neo não desconfia dos ciclos de revolução e retorno à ordem revelados pelo Arquiteto?

O que dá verossimilhança a esse mar de indefinições e inconsistências é a idéia de mecanismo, figurada pela profecia. A crença de que tudo segue o seu curso inexoravelmente é observável em passagens como a seguinte:

Trinity: Maybe we did something wrong.

Neo: Or didn't do something.

Morfeu: No, what happened happened and couldn't have happened any other way.

A mesma fé incondicional em uma abstrata força organizadora dos destinos humanos é vista também na seguinte fala do conselheiro Hamann: 
Neo: Why don't you tell me what's on your mind, Councillor?

Conselheiro Hamann: There is so much in this world that I do not understand. See that machine? It has something to do with recycling our water supply. I have absolutely no idea how it works. But I do understand the reason for it to work. I have absolutely no idea how you are able to do some of the things you do, but I believe there's a reason for that as well.

A conclusão dos filmes é reacionária por várias razões. A primeira delas está no fato de que a série termina deixando um ar de ceticismo e desconfiança em relação à realidade ou não da luta dos humanos contra a Matriz. A possibilidade de tudo não passar de mais uma simulação nunca é desmentida.

A afirmação enfática do "propósito", do papel de cada um (peça) na maquinaria social, e a presença da profecia (organizador de todos os destinos), representam um grande golpe nas possibilidades de agência humana figuradas pelo filme. Com a profecia (que associamos à idéia de mecanismo), temos a figuração da inevitabilidade e da impossibilidade de agência.

Um grande lance de conformismo do filme pode ser visto na trégua final acordada entre os humanos e máquinas. Celebrado como uma vitória, a trégua fecha um ciclo. A trilogia termina onde começou: os humanos continuam escravos do "sistema" e, somente aqueles que possuem "uma natureza 
questionadora" alcançarão a liberdade. Aqui reside o exemplo máximo da epistemologia travada de Matrix: fechado o ciclo, tudo retornando ao que era no início da trilogia, percebemos que a trajetória da resistência humana que acompanhamos nos filmes não passou de um interlúdio revolucionário. Zizek lê o final de "Matrix Revolutions" da seguinte forma maneira:

Perhaps, however - and this would be the only way to (partially, at least) redeem Revolutions - there is a sobering message in this very failure of the conclusion of the Matrix series. There is no final solution on the horizon today, Capital is here to stay, and all we can hope for is a temporary truce ${ }^{132}$.

O que temos de concreto em Matrix, do ponto de vista alegórico, é uma tentativa de figurar a totalidade como um mecanismo fechado e subordinado às leis de seu próprio funcionamento. O universo ficcional construído nesses filmes, com todos os dilemas e ambigüidades que o permeiam, pode ser lido como uma tentativa (um "ato socialmente simbólico") de Darstellung.

A figura da Matriz pode ser lida como um sistema de engenharia social, que coordena todos os destinos individuais em uma grande sinfonia de dominação. Retomemos o trecho em que Zizek fala sobre o "impasse libidinal" de Matrix:

\footnotetext{
${ }^{132}$ ZIZEK, Slavoj. Ideology Reloaded. In In These Times, 6 de junho de 2003. Disponível em http://www.lacan.com/zizekloaded.htm .
} 
Por que a Matriz não mergulha cada indivíduo em seu próprio universo artificial solipsístico? Para que complicar as coisas, coordenando os programas de modo que a humanidade toda habite um único e mesmo universo virtual? ${ }^{133}$

Essas questões apontam para o impulso utópico de Matrix. O que faz com que a figura da Matriz seja construída da forma como foi e não da forma que Zizek aponta como a mais verossímil e racional está no fato de que essa figura é uma tentativa de elaborar formalmente, ainda que de maneira distorcida, um impulso de totalidade, um desejo de abarcar a totalidade das relações sociais. Fazer com que todos os destinos das mentes presas à ilusão da Matriz se cruzem é uma maneira de buscar um "efeito de fechamento". Todos os humanos presos à Matriz compartilham a mesma realidade e estão sujeitos aos mesmos mecanismos de controle. A Matriz é a totalidade de todas as vidas humanas presas a ela.

O que interessa em Matrix é que tudo é constituído como um só todo. Dentro e fora, máquinas e humanos, as dicotomias não se sustentam em Matrix. Todas as ambigüidades e pontos de indefinição que apontamos nesse estudo se fundem aqui: na tentativa de se dar forma à experiência social como um universo de interdeterminações, como um todo em que todas as partes se relacionam, como uma maquinaria, uma Darstellung.

O momento utópico de Matrix está na tentativa de se pensar o mundo como um sistema, e, sobretudo, na idéia de "falha do sistema". Baudrillard

\footnotetext{
${ }^{133}$ Zizek, Slavoj. Matrix: ou os Dois Lados da Perversão In Irwin, William (Org). Matrix: BemVindo ao Deserto do Real, São Paulo: Madras, 2003. p. 281.
} 
aponta um caminho para pensarmos a utopia hoje:

Quando mais hegemônico é um sistema, tanto mais a imaginação é atingida pelo seu menor revés. O desafio, mesmo infinitesimal, é a imagem de uma falha em cadeia. Só esta reversibilidade sem medida comum constitui um acontecimento hoje em dia, na cena niilista e desafectada do político. Só ela mobiliza o imaginário ${ }^{134}$.

Por trás do conformismo de Matrix, está a essência utópica do filme: a imagem do dejà-vu. Em Matrix, o dejà-vu indica uma falha na construção da Matriz e, ao mesmo tempo, uma tentativa do sistema de se readaptar. Uma repetição do passado que explicita, que denuncia a existência do sistema e a possibilidade de falha nesse sistema.

O dejà-vu é a repetição do passado, uma quebra no contínuo temporal do sistema. Essa quebra do sistema é a senha para a ação revolucionária. O conceito de dejà-vu talvez seja a maior contribuição de Matrix para o pensamento revolucionário, pois essa imagem figura a idéia de "falha no sistema", idéia que é repetida em outros momentos da trilogia. Mesmo com sua conclusão conformista, Matrix ainda traz esse indício de mudança, sintoma de uma "estrutura de sentimento" de que a ruptura com o atual é algo possível e necessário.

\footnotetext{
${ }^{134}$ BAUDRILLARD, Jean. Simulacros e Simulação, Lisboa: Relógio D’Água, 1991, p. 200.
} 


\section{Conclusão}

Procuramos, com esse trabalho, oferecer uma leitura de Matrix que desse conta da explosão de significados que esse objeto pode suscitar.

Começamos prestando conta com a literatura crítica escrita sobre esse filme. Com o estudo dessas obras, constatamos o caráter polissêmico da figura da Matriz, fato que constituiu um primeiro obstáculo para a análise do filme.

Para que nossa análise não caísse no buraco negro da polissemia de Matrix optamos por uma leitura dessa obra como "ato socialmente simbólico". Procuramos contextualizar a obra e ler seus problemas e falhas como sintomas de dilemas políticos, sociais e históricos, os quais podem ser rastreados em todo objeto artístico, uma vez que

A realidade social e os estereotípicos de nossa experiência da realidade social cotidiana constituem a matéria prima com que os filmes comerciais e a televisão são inevitavelmente forçados a trabalhar ${ }^{135}$.

Verificamos que, no filme, esses dilemas são formalmente traduzidos e aparecem na forma de falhas e inconsistências no tecido ficcional. Matrix está repleto desses momentos, como vimos.

${ }^{135}$ JAMESON, Fredric. Marcas do visível, Rio de Janeiro : Graal, 1995, p. 39. 
O equilíbrio precário entre autonomia a sua ausência (entre agência e determinação) que vemos no paradoxo da escolha dentro da profecia; as contradições que envolvem a crítica da tecnologia (como a dependência dos resistentes em relação à máquina e a utilização ostensiva de efeitos especiais num filme que se propõe a criticar a onipresença da tecnologia na nossa sociedade); os vários fatos ficcionais que ficam sem explicação no filme (como as motivações de personagens como Smith, a Oráculo, o Merovíngio; como a existência de outros Escolhidos e dos ciclos de destruição e restauração da ordem; como extensão dos poderes de Neo para o mundo real etc...), tudo isso constitui a epistemologia travada de Matrix.

Podemos perceber no filme um impulso de cognição, uma intenção de mapear e descrever dilemas da realidade social (que é transfigurada para a ficção). Na transposição da realidade para ficção, fissuras da realidade social ficam aparentes, uma vez que as respostas simbólicas dadas para esses problemas não conseguem resolvê-los plenamente, e nem poderiam, uma vez que

nem sempre os desejos podem ser fantasiados com sucesso: tal é o resultado dos limites tanto da narrativa, quanto do Real. Da mesma forma, nem sempre se pode realizar uma construção: há limites de material e de situação histórica que funcionam como estática e dinâmica, as leis elementares da 
gravidade e da locomoção, e da construção de coletivos imaginários $^{136}$.

Matrix enfrenta esses limites. Sua epistemologia travada é resultado desse embate. No entanto, são exatamente as falhas de Matrix que constituem a sua maior força, como bem observa Zizek:

De uma maneira adorniana, poderíamos dizer que essas inconsistências são o momento da verdade do filme: elas assinalam os antagonismos de nossa experiência social capitalista, antagonismos esses que concernem pares ontológicos básicos como realidade e dor (realidade como aquilo que perturba o reino do princípio do prazer), liberdade e sistema (a liberdade só é possível dentro do sistema que impede a sua total prática $)^{137}$.

No segundo capítulo dessa dissertação, realizamos um itinerário analítico cujo objetivo era fabricar uma ferramenta teórica que respondesse à especificidade do objeto estudado.

Começamos esse caminho pelo estudo da figura da máquina como elemento retórico. Vimos quais os atributos geralmente associados a essa figura. Passamos a estudar uma certa tradição de emprego retórico e simbólico

\footnotetext{
136 JAMESON, Fredric. Espaço e imagem: teorias do pós-moderno e outros ensaios. Rio de Janeiro: UERJ, 2004. p. 269.

${ }^{137}$ ZIZEK, Slavoj. Matrix: ou os Dois Lados da Perversão In IRWIN, William (Org). Matrix: Bem-Vindo ao Deserto do Real, São Paulo: Madras, 2003. p. 280.
} 
do tópos da máquina. Nesse ponto, introduzimos o conceito de "anticapitalismo romântico" e analisamos como Matrix participa desse tipo de discurso.

Vimos como muitas obras que participam da "tradição" do "anticapitalismo romântico" organizam a sua crítica do atual por meio de pares antinômicos. Com o apoio da análise que Adorno fez do romance Admirável Mundo Novo estudamos os pares antinômicos que aparecem em Matrix.

Em seguida, analisamos a dissolução das antinomias que aparecem em Matrix. Tais antinomias não conseguem se estabelecer, sendo minadas por ambigüidades e indefinições na sua constituição.

Após uma listagem de algumas das inconsistências mais marcantes no enredo de Matrix, chegamos ao ponto crítico da nossa trajetória crítica. O que fazer depois de constatada essa inoperância cognitiva do filme?

Aqui, os conceitos de Darstellung e "efeito de fechamento" nos ajudaram a prosseguir com a análise. Vimos que, em Matrix, há um impulso de se figurar um sistema, um todo maior que harmonize todas as peças em ação no enredo. Vimos a importância da profecia e da figura da Matriz nesse contexto.

Acreditamos que esse desejo de totalidade seja o trunfo de Matrix, seja a sua grande contribuição para a crítica do atual. Mesmo com o seu final melancólico e conformista, Matrix mantém o mérito de pertencer àquele grupo de narrativas que busca figurar uma ruptura, uma fuga do mundo como ele é. Raymond Williams identifica a fuga e a abertura como uma tendência emergente das narrativas utópicas. Para ele, essa é uma renovação bem-vinda do impulso utópico: 
Within a capitalist dominance, and within the crisis of power and affluence which is also the crisis of war and waste, the utopian impulse now warily, self-questioningly, and setting its own limits, renews itself ${ }^{138}$.

Raymond Williams vê essa abertura do impulso utópico como uma força, não uma limitação. Segundo Williams,

Forced open, after the congealing of ideals; the degeneration of mutuality into conservatism; shifted, deliberately, from its achieved harmonious condition, the stasis in which the classical utopian mode culminates, to restless, open, risk-taking experiment. This is a significant and welcome adaptation, depriving utopia of its classical end of struggle, its image of perpetual harmony and rest ${ }^{139}$.

A fuga da Matrix, mesmo com todos os problemas de figuração que 0 filme apresenta, parece encerrar um promissor recado de dias melhores.

138 WILLIAMS, Raymond. Problems in materialism and culture: selected essays. London: Verso, 1980, p. 212.

${ }^{139}$ Ibid., pp. 210-11. 


\section{Referências bibliográficas:}

ADORNO, T. W. Notas de Literatura - vol.1. São Paulo: Duas Cidades; Ed. 34, 2003.

Indústria Cultural e Sociedade. Seleção de textos Jorge

M.B. Almeida. São Paulo: Paz e Terra, 2002.

I HORKHEIMER, M. Dialética do Esclarecimento:

fragmentos filosóficos. Rio de Janeiro: Jorge Zahar, 1985.

. Prismas: crítica cultural e sociedade. São Paulo: Ática,

1998.

ANDRADE, Carlos Drummond de. Nova Reunião: 19 livros de poesia. Rio de Janeiro: José Olympio, 1987.

ANDERSON, Perry. As origens da Pós-Modernidade. Rio de Janeiro: Jorge Zahar, 1999.

BAUDRILLARD, Jean. Simulacros e Simulação. Lisboa: Relógia D’Àgua, 1991.

A Ilusão Vital. Rio de Janeiro: Civilização Brasileira, 2001.

BAUMAN, Zygmunt O Mal-Estar da Pós-Modernidade. Rio de Janeiro: Jorge Zahar, 1999.

BENJAMIN, Walter. Charles Baudelaire: Um Lírico no Auge do Capitalismo.

São Paulo: Brasiliense, 1989, p. 175.

CAMPOS, Maria Teresa Cardoso de. Marcuse: realidade e utopia. São Paulo: Annablume, 2004 
DEBORD, Guy. Commentaires sur la société du spectacle. Paris: Gallimard, 1992.

DIENST, Richard. Still life in real time: theory after television. Durham \& London: Duke University Press, 1994.

DOWLING, William C. Jameson, Althusser, Marx: an introduction to the political unconscious. London: Methuen, 1984.

EAGLETON, Terry. As llusões do Pós-modernismo. Rio de Janeiro: Jorge Hazar, 1998.

E.T.A Hoffmann, "O Homem de Areia" in Contos Fantásticos, Rio de Janeiro: Imago, 1993

FELINTO, Erick. A religião das máquina: ensaios sobre o imaginário da cibercultura. Porto Alegre: Sulina, 2005.

HARAWAY, Donna. A Cyborg Manifesto: Science, Technology, and Socialist-Feminism in the Late Twentieth Century in Simians, Cyborgs and Women: The Reinvention of Nature. New York: Routledge, 1991.

HARVEY, David. A Condição Pós-Moderna. São Paulo: Edições Loyola, 2004.

JAMESON, Frederic. A cultura do dinheiro: ensaios sobre a globalização. Petropolis: Editora Vozes, 2001. . Espaço e imagem: teorias do pós-moderno e outros ensaios. Rio de Janeiro: UERJ, 2004. . O Inconsciente Político: a Narrativa como Ato Socialmente Simbólico. São Paulo: Ática, 1992.

. Postmodernism, or, The cultural logic of late capitalism. London: Verso, 1991. 
. Signatures of the visible. New York: Routledge, 1992.

. The cultural turn: selected writings on the postmodern.

London: Verso, 1998. New York.

. The geopolitical aesthetic: cinema and space in the world

system. Bloomington: Indiana University Press ; 1995.

KURZ, Robert, Os últimos combates. Petrópolis: Vozes, 1998.

LOWY, Michael. Romantismo e Messianismo. São Paulo: Edusp, 1990. Walter Benjamin: aviso de incêndio, Uma leitura das teses

"Sobre o conceito de história". São Paulo: Boitempo, 2005.

LUKACS, Georg. A teoria do romance. São Paulo: Livraria Duas Cidades:

Editora 34, 2003.

MARCUSE, Herbert. Eros e Civilização. Rio de Janeiro: Zahar, 1968.

MATOS, Olgária C. F. A escola de Frankfurt: luzes e sombras do iluminismo. São Paulo: Moderna, 2003.

Os arcanos do inteiramente outro. São Paulo: Brasiliense,

1995.

POE, Edgar Allan. Complete Stories and Poems of Edgar Allan Poe. New York: Doubleday, 1984.

SCHILLER, Friedrich. A Educação Estética do Homem. São Paulo: lluminuras, 1989.

STALLABRASS, Julian. Gargantua: Manufactured Mass Culture. London: Verso, 1996.

STERLING, Bruce. Holy fire. Nova York: Bantam Books, 1996, p. 68.

WILLIAMS, Raymond. Culture and society. London: Chatto \& Windus, 1958. 
. Keywords: a vocabulary of culture and society. New York: Oxford University Press, 1985.

. Problems in materialism and culture: selected essays. London:

Verso, 1980.

. Television: Technology and cultural form. London; New York:

Routledge, 1974.

XAVIER, I. O discurso cinematográfico: a opacidade e a transparência. Rio de Janeiro: Paz e Terra, 1984.

. O Olhar e a Cena: Melodrama, Hollywood, Cinema Novo, Nelson Rodrigues. São Paulo: Cosac \& Naify, 2003.

ZIZEK, Slavoj. Bem-vindo ao Deserto do Real!. São Paulo: Boitempo, 2003.

Sobre a trilogia Matrix:

CHALLIYIL, Pradheep. Journey to the Source: Decoding Matrix Trilogy. USA: Sakthi Books, 2004.

CLOVER, Joshua. The Matrix. London: BFI, 2004.

DAMARIS. Connect: The Matrix, What does the Bible say about... USA: Scripture Union, 2003

FALLER, Stephen. Beyond the Matrix: Revolutions and Revelations. USA:

Chalice Press, 2004. 
GRAU, Christopher (Ed). Philosophers Explore the Matrix. England: Oxford University Press, 2007.

HABER, Karen (Ed). Exploring the Matrix: Visions of the Cyber Present. USA: St. Martin's Press, 2003.

IRWIN, William (Ed). "The Matrix" and Philosophy: Welcome to the Desert of the Real. New York: Open Court, 2002. Traduzido como Matrix: Bem-Vindo ao Deserto do Real. São Paulo: Madras, 2003.

. (Ed). More "Matrix" and Philosophy. New York: Open Court,

2005.

JAKE, Horsley. Matrix Warrior: Being the One. USA: St. Martin's Griffin, 2003.

KAPELL, Matthew \& DOTY, William G. (Eds). Jacking in to The Matrix Trilogy: Cultural Reception and Interpretation. London: Continuum, 2004.

LAMM, Spencer (Ed). The art of The Matrix. New York: Newmarket Press. 2001.

LAVELLE, Kristenea M. The Reality Within The Matrix. Saxco Publishing, 2002.

LAWRANCE, Matt. Like a Splinter in Your Mind: The Philosophy Behind the 'Matrix' Trilogy. Oxford: Blackwell, 2004.

LLOYD, Peter B. Exegesis of the Matrix. New York: Whole-Being Books, 2003.

MARRIOT, Michael. The Matrix Cultural Revolution: How Deep Does the Rabbit Hole Go? New York: Thunder's Mouth Press, 2003.

REZENDE, Julio Francisco Dantas de. Matrix e a administração transpessoal. Rio de Janeiro: E-Papers, 2007. 
SEAY, Christopher; GARRETT, Greg. The Gospel Reloaded: Exploring Spirituality and Faith in The Matrix. USA: Pinon Press, 2003.

YAGER, A.J e VESCERA, Dean. The One (Matrix Book) (Matrix Reprogrammed). USA: Lifeforce Publishing, 2003.

YEFFETH, Glenn (Ed.). Taking the Red Pill: Science, Philosophy, and Religion in 'The Matrix'. Chichester: Summersdale, 2003. Traduzido como $A$ pílula vermelha: questões de ciência, filosofia e religião em Matrix. São Paulo: Publifolha, 2003.

ZACAPA. Eddie. Matrix Reflections: Choosing Between Reality And Illusion. USA: Authorhouse, 2005.

\section{Dissertações:}

REGA, Joseph Mark. Space Doubt: The Progression of Spaces From Metropolis to the Matrix. 01/08/2003. 1v. 85p. Mestrado. UNIVERSIDADE FEDERAL DE SANTA CATARINA.

VEDOVATO, Maurício. O duplo e o simulacro em Blade Runner e em Matrix. 01/02/2003. 1v. 147p. Mestrado. UNIVERSIDADE DE SÃO PAULO. SCHATZ, Sandra Regina. From Frankenstein to Matrix: Cultural perceptions of cyborg. 01/02/2002. 1v. 116p. Mestrado. UNIVERSIDADE FEDERAL DE SANTA CATARINA. 
